\title{
mTOR Regulation of Lymphoid Cells in Immunity to Pathogens
}

\author{
Rachael Keating and Maureen Ann McGargill* \\ Department of Immunology, St. Jude Children's Research Hospital, Memphis, TN, USA
}

Immunity to pathogens exists as a fine balance between promoting activation and expansion of effector cells, while simultaneously limiting normal and aberrant responses. These seemingly opposing functions are kept in check by immune regulators. The mechanistic target of rapamycin (mTOR) is a serine/threonine kinase that senses nutrient availability and, in turn, regulates cell metabolism, growth, and survival accordingly. mTOR plays a pivotal role in facilitating immune defense against invading pathogens by regulating the differentiation, activation, and effector functions of lymphoid cells. Here, we focus on the emerging and sometimes contradictory roles of mTOR in orchestrating lymphoid cell-mediated host immune responses to pathogens. A thorough understanding of how mTOR impacts lymphoid cells in pathogen defense will provide the necessary base for developing therapeutic interventions for infectious diseases.

\section{OPEN ACCESS}

Edited by:

Diana Bahia,

Universidade Federal de Minas

Gerais, Brazil

Reviewed by:

Hridayesh Prakash,

University of Hyderabad, India

Katharina F. Kubatzky,

University Hospital Heidelberg,

Germany

*Correspondence:

Maureen Ann McGargill maureen.mcgargill@stjude.org

Specialty section:

This article was submitted to Microbial Immunology,

a section of the journal

Frontiers in Immunology

Received: 24 December 2015 Accepted: 25 April 2016

Published: 11 May 2016

Citation:

Keating R and McGargill MA (2016) mTOR Regulation of Lymphoid Cells in Immunity to Pathogens.

Front. Immunol. 7:180. doi: 10.3389/fimmu.2016.00180

\section{Keywords: mTOR, immune regulation, pathogen, metabolism, immune differentiation}

The mechanistic target of rapamycin (mTOR) is an evolutionarily conserved serine/threonine kinase that is ubiquitously expressed in immune cells. mTOR integrates multiple environmental signals to regulate diverse cellular processes including protein translation, cell growth, proliferation, metabolism, migration, and survival. Accordingly, mTOR plays a key role in multiple components of both myeloid and lymphoid cell differentiation, activation, and acquisition of effector functions. Through regulation of these key mechanisms, mTOR has an essential role in generating and regulating immune cells to combat pathogens.

The emerging view describes mTOR not as a single trigger for a linear cascade of events, but rather as a multifunctional orchestrator of diverse immune responses. In this review, we detail the current understanding of mTOR as a multifaceted regulator of immunity to pathogens through its impact on lymphoid cells. Specifically, we describe mTOR regulation of natural killer (NK) cells, invariant natural killer $\mathrm{T}$ (iNKT) cells, $\mathrm{CD} 8$ and $\mathrm{CD} 4 \mathrm{~T}$ cells, and B cells during immunity to pathogens. The regulation of myeloid cells has been extensively reviewed recently (1). We also explore how mTOR inhibition may be utilized to enhance immunity to pathogens and discuss implications for vaccine design.

\section{mTOR COMPLEXES AND SIGNALING CASCADES}

Mechanistic target of rapamycin functions as two signaling complexes in mammalian cells: mTOR complex 1 (mTORC1) and mTOR complex 2 (mTORC2) (Figure 1). mTORC1 includes a scaffolding protein, regulatory-associated protein of mTOR (Raptor), DEP-containing mTOR interacting protein (Deptor), mammalian lethal with Sec13 protein (mLST8), and the Proline-Rich AKT substrate (PRAS40). Similarly, mTORC2 also comprises mTOR, Deptor, and mLST8, with the addition of the scaffold protein Raptor-independent Companion of TOR (Rictor), the Protein observed with Rictor (Proctor), and the mammalian stress activated protein kinase-interacting protein 1 (mSIN1). 


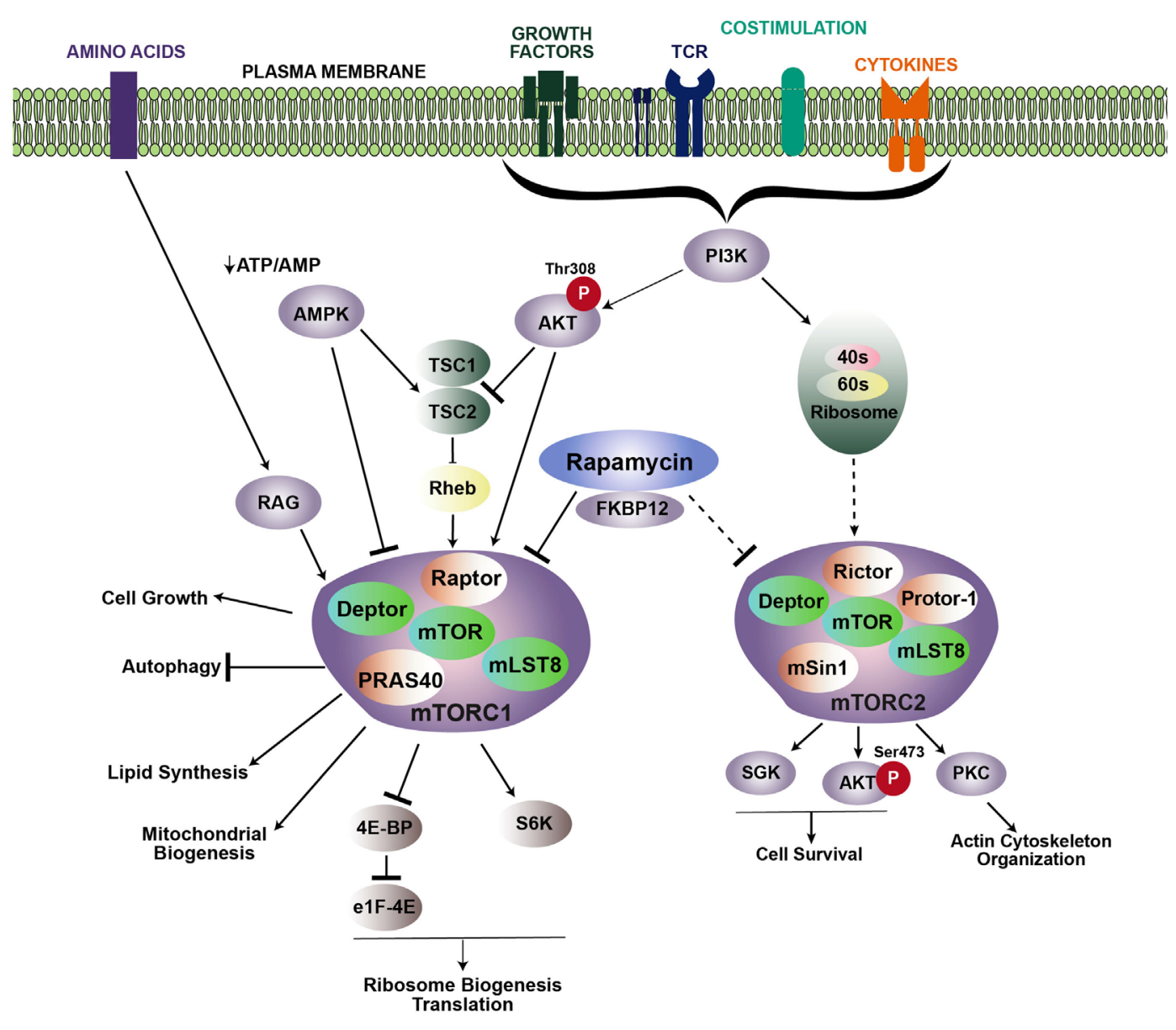

FIGURE 1 | Signaling cascades promoting mTOR activation. mTOR regulates multiple cellular processes via two distinct complexes: mTORC1 and mTORC2. Growth factors, TCR engagement, costimulation, and cytokines all contribute to PI3K activation, which leads to the recruitment of Akt to the membrane, where it is phosphorylated at position threonine 308. Activated Akt then phosphorylates the TSC1/TSC2 inhibitory complex, which releases Rheb and induces accumulation of Rheb-GTP to promote mTORC1 activity. Rapamycin inhibits mTOR by binding to the intracellular partner, FKBP12, which directly inhibits mTORC1. Upstream regulation of $\mathrm{mTORC2}$ is less known, but is downstream of PI3K activation. Association with ribosomes regulates mTORC2 activation. $\mathrm{mTORC2}$ is typically regarded as insensitive to rapamycin; however, prolonged rapamycin treatment can reduce mTORC2 activity. Arrows and bars represent activation and inhibition, respectively. Dashed lines indicate that the exact mechanism is unknown.

mTOR complex 1 is activated in response to various extracellular stimuli including nutrients, growth factors, stress, cytokines, and antigen receptor signaling. When nutrients and these stimuli are readily available, mTORC1 activity is high, and energy-demanding cellular processes such as translation and ribosomal biogenesis are promoted. Extracellular stimuli activate mTORC1 by triggering a signaling cascade through PI3 kinase (PI3K) and the protein kinase, Akt. Akt then phosphorylates the mTORC1 repression factor, consisting of tuberous sclerosis complex 1 (TSC1) and TSC2. Phosphorylation of the TSC complex prevents it from inhibiting Rheb, which is essential for mTORC1 activation. Additionally, mTORC1 can also be activated in a TSC-independent process, whereby Akt blocks inhibition of mTORC1 by phosphorylating PRAS40 to stabilize the mTOR-Raptor interaction $(2,3)$. Activation of mTORC1 leads to phosphorylation of p70-S6 kinase (S6K) and the eukaryotic initiation factor $4 \mathrm{E}$-binding protein $(4 \mathrm{E}-\mathrm{BP} 1)$, which helps regulate translation (4-6). mTORC1 signaling also increases the rate of glycolysis by inducing the expression of HIF- $1 \alpha$ and c-Myc. Conversely, mTORC1 activity is inhibited when nutrient-associated cues are lacking. For example, in response to a decrease in the ATP/ADP ratio, the AMPactivated protein kinase (AMPK) becomes activated, and in turn, inhibits mTOR activity by phosphorylating TSC2 or Raptor.

Activation of mTORC2 is not as well defined as mTORC1. Similar to mTORC1, activation of mTORC2 occurs downstream of P13K. However, activation of mTORC1 occurs downstream of Akt following phosphorylation at threonine 308 (T308), while mTORC2 acts upstream of Akt by phosphorylating serine 473 of Akt (S473). In contrast to mTORC1 activation, mTORC2 activation occurs independent of protein synthesis, but instead, relies on association with the ribosome (7). Activation of Akt by mTORC2 also leads to phosphorylation and inhibition of FOXO1 
and FOXO3 (8). In addition to Akt, mTORC2 also activates serum glucocorticoid-regulated kinase 1 (SGK1) and protein kinase $\mathrm{C}$ alpha $(\mathrm{PKC} \alpha)$. Signaling via mTORC2 is important for reorganization of the cytoskeleton through activation of RhoA GTPase and promoting cell survival by upregulating antiapoptotic proteins $(7,9)$.

Much of the role and function of mTOR has been ascertained with rapamycin, a small molecule drug derived from Streptomyces hygroscopicus. Rapamycin binds a $12-\mathrm{kDa}$ Fk506-binding protein (FKBP12) to form the rapmycin-FKBP12 complex, which binds mTOR and inhibits formation of the mTORC1 complex (10). Prolonged rapamycin exposure also inhibits mTORC2 (11). However, mTORC2 is typically regarded as insensitive to rapamycin. Use of knock-out mice, in particular, mice with a conditional deletion of Raptor, Rictor, Rheb, or Tsc, which are critical components of MTORC1 and MTORC2 complexes, have also greatly advanced our understanding of mTOR signaling pathways and function (Table 1).

Several pathways regulate activation of $\mathrm{mTORC} 1$ and mTORC2. When energy levels are low, mTORC1 is inactivated, and FOXO transcribes Rictor, promoting formation of mTORC2, which phosphorylates Akt S473 (12). Transcription of Rictor and subsequent phosphorylation of Akt $\$ 473$ requires mTORC1 inhibition (13). Similarly, while mTORC1 activates protein synthesis and S6K, S6K activity can repress Rictor and mTORC2 function. In addition, recent studies highlight a positive feedback loop between Akt and mTORC2 via SIN1 phosphorylation, whereby Akt is activated following PDK1 phosphorylation. Next, Akt phosphorylates SIN1, enhancing mTORC2 activity, which then promotes phosphorylation and complete activation of Akt (14).

Pathogens can also influence activation of the mTOR pathway. mTORC1 regulates translation by phosphorylating 4E-BP1, which releases it from the $5^{\prime}$ cap-binding protein, eukaryotic translation initiation factor $4 \mathrm{E}$ (eIF4E) allowing translation to proceed (4-6). Pathogens that are dependent on the host's cellular $5^{\prime}$ cap-dependent translation must therefore maintain mTOR activity, or bypass the need for mTOR-mediated phosphorylation of $4 \mathrm{E}-\mathrm{BP} 1$ to enable the translation complex to form. Indicative of the former approach, human papillomavirus (HPV) uses two early proteins, E6 and E7, to activate mTOR signaling, which phosphorylates and inactivates $4 \mathrm{E}-\mathrm{BP} 1$ to support viral capdependent protein synthesis $(15,16)$. Similarly, Epstein-Barr virus (EBV) activates cap-dependent translation using a viral protein, LMP2A, to activate mTORC1 (17). Adenovirus also uses viral proteins (e4-ORF1 and e4-ORF4) to mimic stimulatory signals and activate mTORC1 activity in the absence of nutrients or growth factors to maintain translation of viral proteins (18). Bacterial pathogens including Listeria monocytogenes (L. monocytogenes) and Staphylococcus aureas can also activate mTOR to promote IL-10 production and increase their survival in the host (19). Alternatively, some pathogens have evolved mechanisms to bypass mTORC1 activity. For example, human cytomegalovirus (HCMV) bypasses mTORC1 activity by directly phosphorylating $4 \mathrm{E}-\mathrm{BP} 1$ and $\mathrm{IF} 4 \mathrm{G}$ to maintain the activity of the translation complex (20). In contrast, some pathogens such as Leishmania major have proteases that block mTOR activation, which suppresses the type 1 IFN response, allowing the pathogen to survive within cells (21). Hence, a pathogen's translation requirements and the ability to resolve these requirements will influence whether the pathogen tries to enhance, bypass, or suppress mTOR activity, and in turn, will influence the counter approach by the host immune response.

\section{mTOR REGULATION OF AUTOPHAGY IN HOST DEFENSE}

Mechanistic target of rapamycin regulates cell processes in response to nutrient availability. A key component of cellular control by mTOR is through regulation of autophagy, which is an essential process in all myeloid and lymphoid cells. Autophagy facilitates turnover of unnecessary or damaged cellular components. These cellular components are surrounded by a doublemembraned vesicle, targeted to a lysome, degraded, and then recycled. This process allows cells to survive under stress. When energy sources are low, mTOR activity is low, biosynthesis is attenuated, and autophagy is upregulated to recycle nutrients, rather than synthesize new material. This prevents translational arrest and cell death. Conversely, when energy and nutrients are readily available, mTOR is active and signals downstream pathways to generate new cellular material to promote cell growth and proliferation, while suppressing autophagy. Basal autophagy levels are essential for homeostatic clearance of protein aggregates and damaged organelles (22). Basal autophagy is regulated independent of mTOR; however, mTOR suppresses autophagy induction above basal levels (23). Regulation of autophagy by mTOR provides an interface for both pathogen assault and host defense, as intracellular pathogens compete with the host for energy and resources.

Stimuli triggered by pathogen infection can induce autophagy above basal levels to destroy intracellular pathogens, while simultaneously increasing the cell surface presentation of microbial antigens to stimulate the immune response. For example, infection with the bacteria, Shigella flexneri, causes amino acid starvation and subsequent downregulation of mTOR to induce autophagy (24). The adaptation of the immune system to detect and respond to intracellular pathogens has simultaneously provoked evolution of some pathogens to circumvent autophagy induction. Indeed, HSV-1 and HSV-2 prevent induction of autophagy to evade immune defense mechanisms $(22,25,26)$. Similarly, L. monocytogenes and Salmonella attempt to subvert induction of autophagy by reactivating mTOR to downregulate the immune response $(24,27)$. Therefore, these pathogens hijack and maintain basal levels of autophagy to exploit host energy supplies and nutrients for their own replication. In such situations, it is beneficial for host defense mechanisms to inhibit mTOR and induce autophagy above basal levels.

In contrast, autophagy induction can benefit some pathogens by supporting their replication. Multiple subtypes of influenza A virus induce autophagy and autophagic cell death by suppressing mTOR to promote replication $(28,29)$. Hence, autophagy inhibitors may limit influenza virus infection. Datan et al. also reported that influenza virus infection induced autophagy in 
TABLE 1 | Overview of studies demonstrating the role of mTOR in lymphoid cells following pathogen infection.

\begin{tabular}{|c|c|c|c|c|c|}
\hline Cell type & mTOR modification & Pathogen & Cellular and pathogen outcome & $\begin{array}{l}\text { Conclusion about mTORs activity } \\
\text { during infection }\end{array}$ & Reference \\
\hline \multirow[t]{2}{*}{ NK cells } & Rapamycin & MCMV & $\begin{array}{l}\text { Blocked proliferation, IFN- } \gamma \text { synthesis and } \\
\text { granzyme B expression. Higher viral titer }\end{array}$ & $\begin{array}{l}\text { Promotes proliferation, IFN- } \gamma \text { synthesis and } \\
\text { granzyme B expression, and pathogen } \\
\text { clearance }\end{array}$ & (33) \\
\hline & $m T O R^{-/-}$NK cells & MCMV & $\begin{array}{l}\text { Blocked proliferation and granzyme B } \\
\text { expression. Higher viral titer }\end{array}$ & $\begin{array}{l}\text { Promotes proliferation and granzyme B } \\
\text { expression and pathogen clearance }\end{array}$ & $(31)$ \\
\hline \multirow[t]{6}{*}{ CD8 effector } & $\begin{array}{l}\text { T cell-specific Tsc2 deletion } \\
\text { to enhance mTORC1 } \\
\text { activity }\end{array}$ & Vaccinia-OVA & $\begin{array}{l}\text { Excessive generation of effector } \mathrm{CD}^{+} \mathrm{T} \text { cells, } \\
\text { unable to differentiate into memory cells. High } \\
\text { cytolytic activity. Robust IFN- } \gamma \text { and TNF- } \alpha\end{array}$ & $\begin{array}{l}\text { mTORC1 promotes generation of effectors } \\
\text { and mTORC1 suppression promotes } \\
\text { memory formation }\end{array}$ & $(57)$ \\
\hline & $\begin{array}{l}\text { T cell-specific Rictor } \\
\text { deletion to inhibit mTORC2 }\end{array}$ & Vaccinia-OVA & $\begin{array}{l}\text { Unaltered CD8 differentiation and effector } \\
\text { function }\end{array}$ & mTORC2 does not regulate effector cells & $(57)$ \\
\hline & $\begin{array}{l}\text { T cell-specific Rheb } \\
\text { deletion to inhibit mTORC1 }\end{array}$ & Vaccinia-OVA & $\begin{array}{l}\text { Reduced CD8 effector function. Decreased } \\
\text { IFN- } \gamma, \mathrm{TNF}-\alpha \text {, and cytolytic function }\end{array}$ & mTORC1 enhances CD8 effector function & $(57)$ \\
\hline & Rapamycin & $\begin{array}{l}\text { LCMV and } \\
\text { Listeria }\end{array}$ & $\begin{array}{l}\text { Impaired CD8 effector function and reduced } \\
\text { pathogen clearance }\end{array}$ & $\begin{array}{l}\text { mTORC1 promotes effector function and } \\
\text { pathogen clearance }\end{array}$ & (59) \\
\hline & Rapamycin & Influenza & $\begin{array}{l}\text { Reduces IRF4 expression, which is required } \\
\text { for effector CD8 T cell differentiation and } \\
\text { expansion. Impaired viral clearance and host } \\
\text { recovery }\end{array}$ & $\begin{array}{l}\text { mTOR regulates IRF4 expression to } \\
\text { impact during CD8 T cell differentiation to } \\
\text { promote pathogen clearance }\end{array}$ & $(61)$ \\
\hline & Rapamycin & $\begin{array}{l}\text { LCMV and } \\
\text { LM-OVA }\end{array}$ & $\begin{array}{l}\text { Impaired effector CD8 T cell number and } \\
\text { function, Reduced IFN- } \gamma \text {, TNF- } \alpha \text {, granzyme } \\
\text { B, and cytolytic activity. Reduced pathogen } \\
\text { clearance and survival }\end{array}$ & $\begin{array}{l}\text { mTORC1 promotes effector function, } \\
\text { pathogen clearance, and host survival }\end{array}$ & (59) \\
\hline \multirow[t]{8}{*}{$\begin{array}{l}\text { CD8 } \\
\text { memory }\end{array}$} & $\begin{array}{l}\text { Rapamycin, } m T O R \text {, and } \\
\text { Raptor deletion }\end{array}$ & LCMV & $\begin{array}{l}\text { Enhanced memory cell quantity, quality, and } \\
\text { persistence }\end{array}$ & $\begin{array}{l}\text { mTORC1 suppresses memory quality and } \\
\text { quantity }\end{array}$ & $(67)$ \\
\hline & $\begin{array}{l}\text { In vitro rapamycin treatment } \\
\text { prior to cell transfer }\end{array}$ & $\begin{array}{l}\text { LCMV-gp } 33 \\
\text { peptide }\end{array}$ & $\begin{array}{l}\text { Enhanced and long-lived memory cell } \\
\text { formation }\end{array}$ & mTORC1 suppresses memory formation & (69) \\
\hline & $\begin{array}{l}\text { In vitro rapamycin treatment } \\
\text { of WT and TRAFG }{ }^{-/-} \text {cells } \\
\text { prior to cell transfer and } \\
\text { infection }\end{array}$ & LM-OVA & $\begin{array}{l}\text { Restored the ability to develop memory cells } \\
\text { and increased the recall response in the } \\
\text { absence of TRAF6 }\end{array}$ & $\begin{array}{l}\text { mTOR blocks memory development and } \\
\text { recall responses }\end{array}$ & $(68)$ \\
\hline & $\begin{array}{l}\text { T cell-specific TSC2 deletion } \\
\text { to enhance mTORC1 } \\
\text { activity }\end{array}$ & LM-OVA & $\begin{array}{l}\text { Effector cells were unaltered. Differentiation of } \\
\text { effector cells to memory cells was impaired. } \\
\text { Recall response was reduced }\end{array}$ & $\begin{array}{l}\text { Excessive mTORC1 activity inhibits } \\
\text { memory formation and is regulated by } \\
\text { Tsc1 }\end{array}$ & $(70)$ \\
\hline & Rapamycin & $\begin{array}{l}\text { LCMV and } \\
\text { LM-OVA }\end{array}$ & Enhanced CD8 memory formation & mTOR suppress memory formation & $(59)$ \\
\hline & Rapamycin & $\begin{array}{l}\text { Canary } \\
\text { poxvirus }\end{array}$ & $\begin{array}{l}\text { Long-term, low dose rapamycin blocked } \\
\text { memory formation. Short-term, high dose } \\
\text { rapamycin enhanced CD8 memory }\end{array}$ & $\begin{array}{l}\text { Sustained, low level mTOR activity } \\
\text { supports memory formation }\end{array}$ & $(71)$ \\
\hline & Rapamycin & Vaccinia virus & $\begin{array}{l}\text { IL-12-dependent increase in memory CD8 } \\
\text { T cells }\end{array}$ & $\begin{array}{l}\mathrm{IL}-12 \text { regulates the } \mathrm{mTORC} 1 \text { block in } \\
\text { formation of memory CD } 8 \mathrm{~T} \text { cells }\end{array}$ & $(76)$ \\
\hline & $\begin{array}{l}\text { T cell-specific Rictor } \\
\text { deletion to inhibit mTORC2 }\end{array}$ & Vaccinia-OVA & Enhanced generation of memory CD8 T cells & mTORC2 limits memory cell formation & $(57)$ \\
\hline $\begin{array}{l}\text { CD8- } \\
\text { resident } \\
\text { memory }\end{array}$ & $\begin{array}{l}\text { Rapmycin shRNA silenced } \\
\text { mTOR }\end{array}$ & $\begin{array}{l}\text { Vesicular } \\
\text { stomatitis virus } \\
\text { (VSV) and } \\
\text { VSV-OVA }\end{array}$ & $\begin{array}{l}\text { Rapamycin increased the quantity of memory } \\
\text { CD8 in the spleen but reduced resident } \\
\text { memory cells in the intestinal mucosa and } \\
\text { vaginal mucosa }\end{array}$ & $\begin{array}{l}\text { mTOR enhanced formation of memory } \\
\text { cells in the intestinal and vaginal mucosa }\end{array}$ & (84) \\
\hline $\begin{array}{l}\text { CD8 } \\
\text { secondary } \\
\text { expansion }\end{array}$ & Rapamycin & $\begin{array}{l}\text { LCMV, Pichinde } \\
\text { virus }\end{array}$ & $\begin{array}{l}\text { IL-15-dependent, virus-induced cell cycling of } \\
\text { memory CD8 cells was blocked }\end{array}$ & $\begin{array}{l}\text { Inflammatory IL-15 activates the } \\
\text { mTORC1-signaling pathway to support } \\
\text { preexisting memory cells and enhance } \\
\text { antiviral protection }\end{array}$ & $(78)$ \\
\hline $\begin{array}{l}\text { CD8 T cell } \\
\text { exhaustion }\end{array}$ & Rapamycin & Chronic LCMV & $\begin{array}{l}\text { Abrogated therapeutic effects of blocking } \\
\text { PD-1, leading to CD8 T cell exhaustion and } \\
\text { failure to control chronic infection }\end{array}$ & $\begin{array}{l}\text { During chronic infection persistent } \\
\text { antigen impairs mTOR activation, allowing } \\
\text { FOXO1 activity to increase and promote } \\
\text { differentiation of terminally exhausted CTLs }\end{array}$ & (79) \\
\hline Tfh cells & $\begin{array}{l}\text { shRNA silenced Rictor or } \\
\text { Raptor }\end{array}$ & LCMV & $\begin{array}{l}\text { Raptor silencing favored Tfh development } \\
\text { over Th1 development. Rictor silencing } \\
\text { favored Th1 over Tfh development }\end{array}$ & $\begin{array}{l}\text { IL-2-mediated mTORC1 activation } \\
\text { promotes Th1 over Tfh development. } \\
\text { mTORC2 activation favors Tfh over TH1 } \\
\text { development }\end{array}$ & $(118)$ \\
\hline
\end{tabular}


TABLE 1 | Continued

\begin{tabular}{|c|c|c|c|c|c|}
\hline Cell type & mTOR modification & Pathogen & Cellular and pathogen outcome & $\begin{array}{l}\text { Conclusion about mTORs activity } \\
\text { during infection }\end{array}$ & Reference \\
\hline \multirow[t]{3}{*}{ B cells } & $\begin{array}{l}\text { Mice hypomorphic for } \\
m T O R \text { and } B \text { cell-specific } \\
\text { deletion of } m T O R\end{array}$ & S. pneumoniae & $\begin{array}{l}\text { Decreased germinal centers, high-affinity } \\
\text { antibodies, and SMH/CSR. Higher mortality in } \\
\text { hypomorphic mTOR mice }\end{array}$ & $\begin{array}{l}\text { mTOR is a critical immunoregulator, } \\
\text { promoting germinal center formation } \\
\text { through AID signaling to generate high } \\
\text { affinity antibodies }\end{array}$ & (125) \\
\hline & $\begin{array}{l}\text { ATP-competitive mTOR } \\
\text { kinase inhibitor (TOR-KIs) }\end{array}$ & Salmonella & $\begin{array}{l}\text { Early (d14) IgM response was unaltered and } \\
\text { lgG2c decreased. Late (d28) IgM increased } \\
\text { and Tfh cell\% increased with some evidence } \\
\text { of increased GC B cells }\end{array}$ & $\begin{array}{l}\text { Partial inhibition of mTOR activity increases } \\
\text { protective IgM responses }\end{array}$ & $(138)$ \\
\hline & Rapamycin & $\begin{array}{l}\text { Influenza } \\
\text { vaccination and } \\
\text { heterosubtypic } \\
\text { challenge }\end{array}$ & $\begin{array}{l}\text { Delayed germinal center formation, reduced } \\
\text { class switching, increased survival. Increased } \\
\text { viral clearance }\end{array}$ & $\begin{array}{l}\text { mTOR supports antibody class switching } \\
\text { and affinity maturation, which may impair } \\
\text { viral clearance to heterosubtypic infection }\end{array}$ & $(137)$ \\
\hline
\end{tabular}

apoptotic cells in the presence of mTORC1 and mTORC2 activity, indicating that alternate regulatory mechanisms may override suppression of autophagy by mTOR (30). The degree to which various pathogens support or inhibit mTOR activity is therefore a reflection of the extent to which autophagy benefits or hinders their own replication, and the degree to which they have evolved to counter host immune responses.

\section{mTOR IN NK CELL ACTIVATION AND EFFECTOR FUNCTIONS}

Natural killer cells are a subset of innate lymphoid cells that limit infection by intracellular pathogens and promote tumor immunosurveillance. The name "natural killer" reflects their capacity to kill target cells without prior antigenic stimulation. NK cells develop from common lymphoid progenitor cells in the bone marrow in a process dependent on proliferation and mTOR. Mice with a conditional deletion of $m T O R$ in NK cells had a dramatic reduction in NK cell development and differentiation due to defects in proliferation (31). Similarly, transplant patients treated with rapamycin had reduced NK cell numbers (32).

Following development and maturation in the bone marrow, NK cells enter the periphery in a metabolically resting, quiescent state. In the periphery, exposure to IL-15 or viruses promotes NK cell activation, leading to an increase in metabolism, cytokine production, and acquisition of cytotoxic effector functions. High IL-15 concentrations are required to activate mTOR (31). Complete NK cell activation requires mTOR signaling, as rapamycin and NK cell-specific deletion of $m T O R$ blocked proliferation and granzyme $\mathrm{B}$ expression in response to in vitro cytokine stimulation, in vitro polyI:C stimulation, and MCMV infection $(31,33,34)$. Consequently, inhibition of mTOR and NK function resulted in higher viral titers following MCMV infection $(31,33)$. Interestingly, IFN- $\gamma$ secretion was unimpaired following MCMV infection in mice with a NK cell-specific mTOR deletion, yet it was blocked in MCMV-infected mice treated with rapamycin (33). This difference could be due to the fact that rapamycin inhibits mTOR in cells other than NK cells, suggesting that
mTOR signaling in other cell types may impact NK cell effector functions. Alternatively, rapamycin may inhibit the mTOR pathway to a different extent than genetic deletion of mTOR in NK cells.

mTOR complex 1 regulates NK cell effector function by enhancing glucose uptake and promoting aerobic glycolysis. Accordingly, directly limiting glycolysis inhibits IFN- $\gamma$ production and granzyme B expression by NK cells (35). Cells infected with pathogens typically increase glucose uptake and glycolysis and therefore, limit the amount of glucose available to surrounding immune cells (36). The effector functions of NK cells may therefore be hindered by the availability of glucose following infection. During the initial phase of MCMV infection, proliferation of NK cells is IL-15 and mTOR dependent. However, NK cell proliferation subsequently becomes IL-15 and mTOR independent, at which point proliferation is driven by activating receptors on the NK cell, such as Ly $49 \mathrm{H}$, which recognizes viral ligands on infected cells, but does not activate $\operatorname{mTOR}(37,38)$. The later, mTOR-independent phase of such immune responses may be an adaptation to maintain NK effector functions with diminishing glucose supplies. Regardless, this model illustrates that immune response kinetics influence the requirement for mTOR signaling in pathogen defense.

\section{MTOR IN INKT CELL DEVELOPMENT, ACTIVATION, AND EFFECTOR FUNCTIONS}

Signaling through mTOR is also important in the development, activation, and effector function of invariant NKT cells (iNKT) cells. iNKT cells share features common with both NK cells and T cells. Similar to NK cells, iNKT cells rapidly produce large amounts of cytokines following activation, including IFN- $\gamma$, TNF- $\alpha$, IL-4, and IL-17. However, unlike NK cells, iNKT cells express a $\mathrm{T}$ cell receptor (TCR) similar to conventional T cells, albeit at intermediate levels and with decreased diversity. In mice, the iNKT TCR consists of a V $\alpha 14 \mathrm{~J} \alpha 18 \alpha$-chain paired with V $\beta 2$, $\mathrm{V} \beta 7$, or $\mathrm{V} \beta 8.2 \beta$ chains. The iNKT cell TCR recognizes lipid antigens bound to the non-classical major histocompatibility 
complex (MHC) homolog, CD1d. These cells contribute to tumor immunity, autoimmunity, and immunity to pathogens.

Invariant natural killer $T$ cells can be divided into subsets based on transcription factor expression and cytokine production. Expression of the transcription factors T-bet, GATA3, and ROR $\gamma \mathrm{t}$ define the NKT1, NKT2, and NKT17 subsets, respectively (39, 40). Mice with a conditional deletion of Raptor in T cells showed that mTORC1 is required for the development of the NKT1 subset, and to a lesser degree, NKT2 cells $(41,42)$. Furthermore, the remaining iNKT cells were functionally compromised, as they failed to produce IFN- $\gamma$ and TNF- $\alpha$ following stimulation with $\alpha$-Gal-Cer. These data indicate that mTORC1 is differentially required for NKT cell development and effector functions.

While mTORC1 was required for development of NKT1 and NKT2 cells, mice with abrogated mTORC2 signaling had a defect in NKT17 development (43). Moreover, development of NKT17 cells was enhanced in a Rictor-dependent manner in the absence of PTEN, further clarifying that differentiation of the NKT17 lineage is mTORC2 dependent, but mTORC1 independent. However, Prevot et al. found that mTORC2 was required for the development of NKT2, but not NKT1 or NKT17 cells (44). The reason for this inconsistency is not known as both studies used mice with a conditional deletion of Rictor in $\mathrm{T}$ cells for their studies. Possible factors that contribute to such variable findings include diverse microbiomes associated with the different facilities, use of different markers to identify iNKT cell subsets, and technical difficulties associated with the reagents available to analyze iNKT cell transcription factors. An intriguing study recently showed that in the presence of IL-10 and rapamycin, iNKT cells expressed Foxp3 and acquired properties associated with immunosuppressive regulatory cells, identifying yet another population of iNKT cells: Foxp $3^{+}$iNKT cells (iNKTregs) (45).

Stimulation of iNKT cells with $\alpha$-Gal-Cer activates mTOR signaling (46). Mice with an inducible deletion of Raptor in mature iNKT cells showed that mTORC1 signaling is required for optimal proliferation and IL-4, IFN- $\gamma$, and TNF- $\alpha$ synthesis following in vitro and in vivo stimulation with $\alpha$-Gal-Cer (42). Moreover, Raptor deficiency inhibited iNKT-mediated autoimmune hepatitis, which arises in part, due to TNF- $\alpha$ produced by iNKT cells, further highlighting a role for mTOR in regulating iNKT cell effector function.

A role for iNKT cells in pathogen defense is clearly evident following their activation with artificial ligands during infection with different pathogens including malaria (47), HIV (48), influenza virus (49), and hepatitis B virus associated hepatic carcinoma (50). In addition, iNKT cells mediate pathogen defense against several strains of bacteria that express microbial glycolipids and diacylglycerols capable of binding CD1d molecules, such as Streptococcus pneumoniae $(51,52)$, Novosphingobium aromaticivorans (53), and Borrelia burgdorferi (52). At present, mTOR has not been implicated in pathogen responses mediated by iNKT cells. However, as mTOR is required for the development and function of iNKT cells, it is perhaps only a matter of time before a role for mTOR in regulating pathogen defense by iNKT cells is established.

\section{mTOR IN CD8 T CELL IMMUNITY TO PATHOGENS}

$\mathrm{CD}^{+} \mathrm{T}$ cells play a pivotal role in host defense against pathogens by directly killing infected cells via release of cytotoxic granules containing granzymes and perforin, and indirectly through cytokine secretion. A critical role for mTOR is implicated in several stages of CD8 $\mathrm{T}$ cell-mediated immunity including activation, differentiation, migration, and memory formation.

Naive $\mathrm{CD} 8^{+} \mathrm{T}$ cells undergo sequential stages of activation, clonal expansion, and differentiation to generate pathogenspecific effector $\mathrm{CD} 8^{+} \mathrm{T}$ cells. Activation of naive $\mathrm{CD} 8^{+} \mathrm{T}$ cells requires recognition of their cognate antigen presented by $\mathrm{MHC}$ class I molecules on the surface of antigen-presenting cells (APC). Engagement of the TCR with antigen and MHC, in the context of costimulation, induces PI3K signaling and subsequent activation of mTORC1 via TSC1-dependent and -independent processes. Activation of mTORC1 independent of TSC1 occurs through binding of the chaperone protein, Hsp90 to Raptor. The interaction of Hsp90 and Raptor promotes mTORC1 activation and prevents $\mathrm{T}$ cell anergy, as activation of $\mathrm{T}$ cells during a blockage of Hsp90 led to T cell tolerance (54).

One way in which mTOR regulates $\mathrm{T}$ cell activation is by blocking negative regulators of $\mathrm{T}$ cell activation. In particular, naive $\mathrm{CD} 8^{+} \mathrm{T}$ cells are kept in a state of quiescence by several transcription factors including KLF4 and E74-like factor 4 (ELF4). Signaling through mTOR inhibits KLF4 and ELF4 and reverses quiescence following TCR engagement, allowing $\mathrm{CD}^{+}$ $\mathrm{T}$ cell activation and proliferation to proceed (55).

Following $\mathrm{CD}^{+} \mathrm{T}$ cell activation, antigen-specific $\mathrm{T}$ cells undergo clonal expansion and differentiate into effector cells. Progression to effector $\mathrm{CD}^{+} \mathrm{T}$ cells is coordinated with a switch from catabolism to anabolism and oxidative glycolysis. $\mathrm{CD} 8^{+} \mathrm{T}$ cells drastically increase their glucose metabolism as they respond to pathogens and differentiate into effectors (56). Signaling through mTORC1 promotes glycolysis in effector $\mathrm{CD} 8^{+} \mathrm{T}$ cells, and mTOR inhibition with rapamycin suppresses this process. Indeed, $\mathrm{CD} 8^{+} \mathrm{T}$ cells deficient in $\mathrm{mTORC} 1$ signaling failed to develop into effector cells following Vaccinia infection $(57,58)$. Likewise, rapamycin treatment during crucial stages of infection impaired glycolysis and impeded $\mathrm{CD} 8^{+}$effector function and pathogen clearance during infection with lymphocytic choriomeningitis virus (LCMV) and L. monocytogenes (59). Conversely, genetic deletion of $T s c 2$ and enhanced mTORC1 activity led to excessive generation of $\mathrm{CD}^{+}$effector cells. Importantly, constitutively activate mTORC1 produced terminally differentiated effector cells and impaired memory development (57). While mTORC1 activity is required to generate effective $\mathrm{CD} 8^{+}$ effector cells, mTORC2 appears to be dispensable as mice with a conditional deletion of Rictor exhibit normal proliferation and effector functions (57).

Effector differentiation of $\mathrm{CD} 8^{+} \mathrm{T}$ cells is tightly regulated by several transcription factors. The transcription factor HIF- $1 \alpha$ is required to sustain glucose metabolism and expression of perforin and granzymes in effector CD8 ${ }^{+} \mathrm{T}$ cells (58). HIF- $1 \alpha$ controls glycolysis by regulating expression of the glucose transporter, 
Glut1. As $\mathrm{CD}^{+} \mathrm{T}$ cells differentiate into effectors, they increase expression of HIF- $1 \alpha$ in an mTORC1- and IL-2-dependent manner. Therefore, inhibition of mTORC1 with rapamycin inhibits HIF- $1 \alpha$ and Glut 1 expression, glucose uptake, and glycolysis (58). Signaling through mTOR also promotes glycolysis via the oncogene c-MYC, which regulates metabolic reprograming in $\mathrm{T}$ cells following activation (60). Expression of c-MYC is upregulated in an mTOR-dependent manner following TCR stimulation and influences the expression of rate-limiting glycolytic enzymes (60).

Although the HIF- $1 \alpha$ complex is required to sustain glycolytic metabolism in $\mathrm{CD}^{+} \mathrm{T}$ cells, it is not required to initiate the process nor is it essential for $\mathrm{T}$ cell proliferation (58). In contrast, the transcription factor interferon regulatory factor 4 (IRF4) was critical for proliferation and survival of $\mathrm{CD}^{+} \mathrm{T}$ cells responding to infection with influenza virus and L. monocytogenes (61, 62). IRF4 maintains aerobic glycolysis and effector functions in activated $\mathrm{CD}^{+} \mathrm{T}$ cells by promoting the expression of multiple glycolytic enzymes (62). IRF4 expression in $\mathrm{CD}^{+} \mathrm{T}$ cells is regulated by $\mathrm{mTOR}$, and is proportional to the strength of TCR stimulation, such that strong TCR stimulation increases mTOR activity, which enhances IRF4 expression and $\mathrm{CD}^{+} \mathrm{T}$ cell expansion and effector differentiation. Conversely, rapamycin treatment reduced mTOR signaling and impaired IRF4 expression and $\mathrm{CD}^{+} \mathrm{T}$ cell differentiation, leading to impaired viral clearance and host recovery from infection (61).

SEMA4A is a class IV semaphorin that activates mTORC1 signaling and is also required for optimal $\mathrm{CD} 8^{+} \mathrm{T}$ cell activation and differentiation (63). SEMA4A-mediated mTOR signaling was not important in the early phases of $\mathrm{CD} 8^{+} \mathrm{T}$ cell activation, but was important for acquisition of effector functions. Interestingly, IRF4 expression was unaltered in SEM4A4-deficient mice, yet effector differentiation was impaired, indicating that IRF4-dependent signaling may be necessary, but not sufficient, for differentiation of $\mathrm{CD}^{+}$effector T cells. Furthermore, the SEMA4A-plexin B2 axis shifts mTOR-mediated signaling from mTORC2 to mTORC1 in $\mathrm{CD}^{+} \mathrm{T}$ cells $(63)$.

After expansion in the lymph nodes, effector $\mathrm{CD}^{+} \mathrm{T}$ cells travel to the site of infection to kill infected cells. Migration from the lymph node to the site of infection is in part, due to downregulation of CD62L and CCR7, which is dependent on activated mTOR (64). Such regulation by mTOR is evident from maintenance of CD62L and CCR7 in cells treated with rapamycin, leading to the accumulation of these cells in the secondary lymphoid organs rather than non-lymphoid tissue (65).

Following the dramatic $\mathrm{CD} 8^{+} \mathrm{T}$ cell expansion, and subsequent clearance of the pathogen, T cells go through a contraction phase leaving a resolute population of memory cells. The transition from effector to memory cells is coordinated with a transition from high mTOR activity to low mTOR activity. In contrast to $\mathrm{CD}^{+}$effector T cells, which favor glucose over fatty acid metabolism for energy, memory cells are less glycolytic and rely on lipid metabolism to break down fatty acids, amino acids, and glucose interchangeably (66).

The role of mTOR in regulating the transition from effector to memory cells has been studied extensively. Treatment of mice with a low dose of rapamycin or genetic depletion of
Raptor-enhanced memory CD8 ${ }^{+} \mathrm{T}$ cell formation by promoting the generation of memory precursor cells, indicating that high mTOR signaling suppresses memory $\mathrm{CD}^{+} \mathrm{T}$ cell differentiation $(67,68)$. Similarly, adoptive transfer of LCMV-specific T cells cultured with rapamycin showed an increase in oxidative phosphorylation and were long-lived, compared to non-treated cells (69). Conversely, increasing mTOR via Tsc1 deletion in T cells led to a decrease in memory $\mathrm{T}$ cells following $L$. monocytogenes infection, suggesting that TSC1 promotes memory CD8 ${ }^{+} \mathrm{T}$ cell formation by regulating mTOR activity (70). While reducing mTOR signaling increases memory $\mathrm{T}$ cells, it comes at the expense of an optimal primary effector response, which occurs due to impaired glycolysis in the $\mathrm{CD}^{+} \mathrm{T}$ cells after activation (59).

Although a low dose of rapamycin can augment memory formation in response to certain pathogens, long-term blockage of mTORC1 with the same low dose of rapamycin abrogated formation of memory $\mathrm{CD}^{+} \mathrm{T}$ cells in response to canary poxvirus vaccination (71). In this study, a short duration of a high dose of rapamycin during the expansion phase enhanced memory $\mathrm{CD}^{+} \mathrm{T}$ cell responses. Several factors could contribute to these observed differences in generating memory cells with rapamycin, including the strength of TCR stimulation, the level of mTOR activity induced with each pathogen, differential requirements and timing of pathogen replication, and experimental differences in the location (blood versus lymph node and spleen) where the $\mathrm{T}$ cells were analyzed. A recent study indicated that signaling through IFN- $\gamma$ R, with low, but not high TCR signaling, promoted mTOR signaling and generation of short lived effector cells, while simultaneously blocking the formation of memory precursors (72). Given that TCR signaling differs between pathogens, pathogen dose, and even between epitopes of the same pathogen (73), it is not surprising that rapamycin has varied impacts on the CD8 response to different pathogens. In addition, Rictor-deficient mice showed enhanced generation of memory $\mathrm{CD}^{+} \mathrm{T}$ cells, which implicates mTORC2 in suppressing memory cell formation (57). As mTORC2 does not impact formation of effector cells, yet suppresses memory formation, inhibition of mTORC2, rather than mTORC1, may provide an alternate means to boost CD8 memory T cells.

Studies investigating CD8-mediated tumor immunity demonstrate that mTOR controls memory CD8 ${ }^{+} \mathrm{T}$ cell differentiation by regulating two transcription factors, T-bet and Eomesodermin (Eomes) $(74,75)$. In vitro inhibition of $\mathrm{mTOR}$ with a low dose of rapamycin reduced T-bet expression and enhanced Eomes expression in $\mathrm{CD}^{+} \mathrm{T}$ cells, leading to augmented memory responses following adoptive transfer in vivo (74). A recent study indicates that mTOR also controls vaccinia virus-specific $\mathrm{CD}^{+}$ $\mathrm{T}$ cell differentiation by regulating T-bet (76). Therefore, it is likely that mTOR similarly regulates memory differentiation in response to pathogens through T-bet and Eomes.

The effector to memory cell transition is also coupled with the cytokine environment, which appears to be critical for optimal memory development (77). Activation of mTOR by IL-7 promotes T-bet expression and upregulates IL-2R $\beta$. This, in turn, allows IL-15, which also utilizes IL-2R $\beta$ for signaling, to promote differentiation of effector cells to memory cells through 
the upregulation of Eomes (75). IL-15 appears to be particularly important in promoting optimal memory following LCMV infection by transiently inducing cell-cycle progression, independent of antigen re-encounter, via a mTORC1-dependent pathway. This induces more rapid cell division and more protective memory cells following encounter with viral antigen (78). Thus, mTOR signaling impacts multiple stages of $\mathrm{T}$ cell activation and memory formation, and the impact of mTOR signaling can have different outcomes based on the stage of cellular differentiation.

An additional role for mTOR in regulating $\mathrm{T}$ cell exhaustion in response to chronic infection has emerged (79). T cell exhaustion refers to a state of dysfunction marked by reduced effector functions due to the persistence of antigen and inflammation (80). Following chronic LCMV infection, Akt and mTOR signaling were impaired in $\mathrm{CD}^{+}$effector T cells. This reduction in mTOR activity led to increased activity of the transcription factor, FOXO1 and subsequent upregulation of the inhibitory receptor, programed cell death protein 1 (PD-1), which promotes $\mathrm{CD}^{+}$ $\mathrm{T}$ cell exhaustion (79). Blockade of PD-1 increased mTOR activity and decreased $\mathrm{CD} 8^{+} \mathrm{T}$ cell exhaustion. Furthermore, suppression of the mTOR pathway abrogated the therapeutic effects of PD-1 blockade, suggesting that mTOR activity is required to reverse T cell exhaustion by PD-1 blockade.

Recently, a population of long-lived, resident memory CD8 ${ }^{+}$ $\mathrm{T}$ cells $\left(\mathrm{T}_{\mathrm{RM}}\right)$ that resides in peripheral tissues has been defined. $\mathrm{T}_{\mathrm{RM}}$ cells are non-recirculating memory $\mathrm{T}$ cells located at barrier sites, including the skin and mucosal tissue $(81,82)$. Reactivation of $\mathrm{T}_{\mathrm{RM}}$ stimulates innate immunity against antigenically unrelated pathogens, and could potentially enhance vaccine efficacy (83). While rapamycin promotes memory development in lymphoid tissues, it blocks formation of $\mathrm{T}_{\mathrm{RM}}$ cells (84). Specifically, rapamycin treatment blocked formation of Vesicular stomatitis virus (VSV)-specific $\mathrm{T}_{\mathrm{RM}}$ cells in the intestine and vaginal mucosa; however, lung $\mathrm{T}_{\mathrm{RM}}$ cells were unaltered (84). Thus, mTOR appears to promote formation of mucosal resident memory cells in specific tissues following VSV infection. As such, promoting mTOR activation rather than inhibiting it may prove more beneficial in enhancing formation of $\mathrm{T}_{\mathrm{RM}}$ cells.

In summary, signaling mediated by $\mathrm{mTOR}$ has diverse roles in $\mathrm{CD}^{+} \mathrm{T}$ cell-mediated immunity to pathogens including activation of naive precursors, migration of pathogen-specific cells, development of effector functions, regulation of chronically stimulated effector cells, and generation of stable memory cell populations. Each of these stages poses a potential for immune intervention. However, with such diverse roles, therapeutic regulation of the mTOR pathway will require extensive analysis of the potential implications.

\section{mTOR IN CD4 T CELL DIFFERENTIATION AND IMMUNITY TO PATHOGENS}

$\mathrm{CD}^{+} \mathrm{T}$ cells play both supportive and direct roles in host defense against pathogens. As helper cells they regulate the responses of innate immune cells, cytotoxic $\mathrm{CD} 8^{+} \mathrm{T}$ cells, and antibody-forming B cells. In particular, CD4 T cells are absolutely required for generating long-lived, protective antibodies. As direct effectors, CD4 T cells can utilize perforin-dependent cytolysis of infected cells $(85,86)$. Similar to $\mathrm{CD}^{+} \mathrm{T}$ cells, naive $\mathrm{CD} 4^{+} \mathrm{T}$ cells are initially primed in secondary lymphoid organs following binding of their TCR to microbial peptides presented by APCs. CD4 ${ }^{+}$TCR engagement, coupled with co-stimulation, leads to PI3K signaling, mTOR activation, and subsequent development into effector and memory populations (87).

Following antigen encounter, naive $\mathrm{CD}^{+} \mathrm{T}$ cells can differentiate into several distinct subsets including $\mathrm{T}$ helper cells (Th1, Th2, and Th17), T follicular helper cells (Tfh), effector cells, and regulatory $\mathrm{T}$ cells (Treg). Each $\mathrm{CD}^{+} \mathrm{T}$ cell lineage is associated with the expression of specific transcription factors: T-bet (Th1), Gata-3 (Th2), ROR yt (Th17) Foxp3 (Treg), and Bcl-6 (Tfh) (88). mTOR is a key regulator of differentiation of $\mathrm{CD}^{+}$ $\mathrm{T}$ cells. Specifically, differentiation into Th1, Th2, and Th17 cell lineages was severely inhibited in $m T O R$-deficient mice, even in the presence of polarizing cytokines $(87,89)$. In the absence of mTOR signaling, impaired phosphorylation of STATs in response to cytokine stimuli blocked the induction of the lineage specific transcription factors $(89,90)$. Conversely, suppression of mTOR with rapamycin or genetic deletion of $m T O R$ in T cells promoted differentiation to $\mathrm{FoxP}^{+}$Treg cells, indicating that mTOR signaling blocks Treg development (89).

Subsequent studies using conditional deletion of Raptor, Rheb, or Rictor in T cells ascertained the contribution of mTORC1 and mTORC2 in T helper differentiation. Deficiency of Rheb, which is an activator of mTORC1 signaling, impaired differentiation of Th1 and Th17 cell lineages (91). However, Raptor-deficient T cells showed a defect in Th17, but not Th1 differentiation (92). More recently, it was shown that Th2 differentiation was also drastically compromised in the absence of Raptor (93). On the other hand, deficiency of Rictor and mTORC2 signaling impaired Th2 differentiation, but not Th1 or Th17 (91). However, a conflicting study suggested that mTORC2 signaling was also required for Th1 and Th2 differentiation (94). Furthermore, the loss of Th2 differentiation observed in Rictor-deficient $\mathrm{T}$ cells was comparatively minor compared to the loss observed following rapamycin treatment of Rictor-deficient $\mathrm{T}$ cells, indicating a more prominent role for mTORC1 in Th2 differentiation (93). Thus, it is clear that both mTORC1 and mTORC2 complexes play important roles in Th differentiation; however, the precise roles of each pathway in each of the subsets remain to be resolved.

Similar to $\mathrm{CD}^{+}{ }^{+} \mathrm{T}$ cells, differentiation of naive $\mathrm{CD} 4^{+} \mathrm{T}$ cells to Th1, Th2, and Th17 effector cells represents a shift from oxidative phosphorylation to glycolysis. Th1, Th2, and Th17 cells express high levels of Glut1 and are highly glycolytic via mTOR signaling, which sustains their high energy consumption and supports their diverse effector functions (95). Development and maintenance of Th17 cells, in particular, is heavily reliant on glycolysis, which is stimulated by HIF- $1 \alpha$ downstream of $\operatorname{mTOR}(96,97)$. Therefore, signaling through mTOR contributes to resistance to a variety of pathogens via regulating transcription factors essential for developing T-helper subsets, and by maintaining glycolysis of these subsets following activation. 


\section{mTOR IN Treg CELL-MEDIATED IMMUNITY TO INFECTION}

Regulatory $\mathrm{T}$ cells contribute most significantly to pathogen defense by suppressing $\mathrm{T}$ cell responses to limit immunopathology following infection (98). Foxp $3^{+}$expression distinguishes Treg cells from conventional $\mathrm{T}$ cells and confers Treg cell function $(99,100)$. Inhibition of mTOR signaling through either genetic deficiency or rapamycin treatment promoted expansion of preexisting Treg cells $(89,101-103)$ and induced the Treg cell phenotype on conventional T cells and Th17 cells $(96,104-106)$. Thus, mTOR is critical for negatively regulating Foxp3 expression and Treg cell numbers.

The stability and function of Treg cells is influenced by inflammation. In particular, Foxp3 Treg cells can be reprogramed into Th1 and Th17 effectors in the gut or sites of parasitic infection. However, reprograming of Treg cells into Th1/Th17 effectors is blocked with rapamycin, which stabilizes Foxp3 expression in vivo (107). Thus, mTOR signaling promotes differentiation of Treg cells into $\mathrm{T}$ helper cells when needed. Indeed, both Th17 and Treg cells require TGF- $\beta$ for their differentiation, and the degree of mTOR activation delineates the relative development of each cell type. High levels of mTOR activation promote Th17 cell differentiation (108), whereas low mTOR signaling promotes Treg accumulation and sensitizes Treg cells to TGF- $\beta(87,109)$.

Furthermore, mTOR orchestrates a metabolic checkpoint for the differentiation between Treg cells and Th17 cells. Conditions that induced Th17 differentiation led to an induction of HIF$1 \alpha$, which was dependent on mTOR signaling (96). HIF- $1 \alpha$, in turn, increased the expression of glycolytic enzymes and Th17 development, while simultaneously dampening Treg cell development. Thus, blocking glycolysis and mTOR promotes Treg cell generation by downregulation of HIF-1 $\alpha$ (96). Similarly, the ratio between Th1 and Treg cells is also regulated by sphingosine 1-phosphate (S1P), which signals through mTOR and attenuates activity of SMAD3 to antagonize TGF- $\beta$, and inhibit generation of Treg cells and promote Th1 development (110).

In general, mTOR signaling suppresses Treg cell differentiation in favor of $\mathrm{T}$ helper differentiation, which increases immunity to pathogens by supporting the antimicrobial effector functions of T helper cells. Inhibition of mTOR can support development of Treg cells to restrain and control immune responses to circumvent excessive immunopathology. However, Raptor deficiency specifically in Treg cells unexpectedly impaired the suppressive function of Tregs and resulted in a fatal inflammatory disease, suggesting that the mTORC1 complex is also important to maintain Treg homeostasis and function (111). These seemingly contradictory data again highlight the complexity of the mTOR complexes, and the need to further delineate this signaling pathway.

\section{mTOR IN Tfh CELL IMMUNITY TO PATHOGENS}

Tfh cells are a subset of differentiated $\mathrm{CD} 4^{+} \mathrm{T}$ cells with a crucial role in initiating and maintaining germinal center reactions and high affinity isotype-class-switched antibody responses (112).
Thh cells express the transcription factor, Bcl6, which defines Tfh cells and promotes expression of the chemokine receptor, CXCR5 (113-115). In contrast to differentiation of Th1, Th2, and Th17 cells, which is supported by IL-2-mediated activation of mTOR, differentiation of Tfh cells is suppressed by IL-2 activation of mTOR. Th1 differentiation requires STAT5 activation and subsequent Blimp-1 expression, whereas Th cells develop when Blimp-1 synthesis is suppressed, enabling Bcl6 expression $(116,117)$. Indeed, Blimp-1 and Bcl6 expression are mutually exclusive, and over expression of either drives differentiation of Th1 or Tfh cells, respectively (113). During acute LCMV infection, Akt and mTOR signaling were essential for Blimp-1 and T-bet expression, which induced Th1 differentiation and countered Tfh development (118). Silencing of Rictor or Raptor demonstrated that mTORC1 suppresses Tfh cell development and induces Th1 cells, while mTORC2 may suppress Th1 cell development to permit preferential differentiation of Tfh cells in response to LCMV infection (118). Thus, commitment to either Th1 or Tfh lineages is discerned by the level of IL-2-STAT5-mTOR signaling, with increased signaling correlating with the Thl transcription factors, T-bet and Blimp1, and lower IL-2-STAT5-mTOR levels with the Tfh transcription factor, Bcl6 (115, 116, 119-121).

A recent study demonstrated that during influenza virus infection, TGF- $\beta$ opposes IL- 2 to produce more Tfh cells and isotype-switched antibody responses rather than Th1 cells (122). TGF- $\beta$ suppressed mTOR activation in T cells early during infection, which promoted Tfh cell differentiation by limiting IL-2 signaling. Inhibition of mTOR with rapamycin also promoted Tfh cell differentiation, suggesting that TGF- $\beta$ restricts IL- 2 responsiveness and insulates early Tfh progenitor cells from mTOR signaling to promote Tfh cell differentiation and isotype-switched antibody responses (122).

Bcl6 expression in Tfh cells downregulates genes associated with glycolysis, while T-bet in Th1 cells inhibits Bcl6-mediated repression of these genes to promote glycolysis (123). Accordingly, Th cells are less proliferative, and less glycolytic than Th1 cells, due to a lack of IL-2 signaling and a lower level of mTOR activation. Thh cells therefore have a reduced metabolic capacity, similar to Treg cells, and also utilize oxidative phosphorylation for cellular maintenance (118).

Similar to the reciprocal relationship between Th17 and Treg cell activation, mTOR activation also plays a key role in regulating the balance between Th1 versus Thh responses. While both Treg and Tfh cells are suppressed by mTOR activity and share metabolic similarities, Treg cells typically suppress and control immune responses, whereas Th cells typically promote immune responses, primarily germinal center formation and high affinity antibody responses.

\section{mTOR IN B CELL-MEDIATED IMMUNITY TO PATHOGENS}

$\mathrm{B}$ cells are responsible for producing pathogen-specific antibodies that block infection and control pathogen spread. Once generated, antibodies persist to provide long-lasting immunity. B cells develop in the bone marrow through several stages of maturation 
and differentiation that are influenced by mTOR signaling. Mice with a hypomorphic allele of mTOR have a partial block in B cell development in the bone marrow, and altered proportions of $\mathrm{B}$ cell subsets in the spleen (124). Conditional deletion of mTOR in B cells via CD19-cre did not abrogate development, but decreased mature, T2 transitional, and marginal zone B cells in the spleen (125). In addition, B cells lacking components of the mTORC2 complex had altered development. B cells deficient in $\operatorname{Sin} 1$ accumulated at the pro-B cell stage in the bone marrow, and had a reduced capacity to become $\operatorname{IgM}^{+}$immature $\mathrm{B}$ cells due to decreased Akt activation (126). Conditional deletion of Rictor, mediated by Vav-cre, did not perturb B cell development in the bone marrow, but did reduce mature B cells in the spleen (127). Interestingly, conditional deletion of $T s c 1$ in $\mathrm{B}$ cells, which renders mTOR constitutively active, also impaired B cell maturation and significantly reduced marginal zone B cells $(128,129)$. Together, these studies show that both a reduction in mTOR activity and constitutive activation of mTOR can negatively impact B cell development, suggesting that the level of mTOR activation in $\mathrm{B}$ cells is critical for optimal B cell development.

Following development in the bone marrow, B cells migrate to secondary lymphoid organs and mature into follicular or marginal zone B cells, and remain quiescent until stimulated. B cells exhibit basal levels of mTOR activity in response to nutrients without stimulation. mTOR activity levels vary across B cell types, with marginal zone B cells maintaining high levels of mTOR activity, and follicular B cells having lower levels of mTOR activity (130). Activation through the BCR, TLR, or CD40 induces mTOR signaling (131). Similar to T cells, initial B cell activation increases glucose uptake and glycolysis to promote clonal expansion, which is also dependent on the mTOR pathway. Rapamycin inhibited $\mathrm{B}$ cell proliferation in response to anti-CD40, LPS, BAFF, and the polyclonal activator, $S$. aureus (131-136). In addition, B cells expressing the hypomorphic allele of mTOR had decreased proliferation in response to anti-IgM, anti-CD40, and LPS, with a bigger reduction following anti-IgM and anti-CD40 than LPS (124). These data demonstrate that mTOR signaling is essential for B cell proliferation in response to multiple stimuli.

Upon activation, $\mathrm{B}$ cells can either differentiate rapidly into plasmablasts that secrete low affinity IgM antibodies, or form germinal centers within secondary lymphoid organs, which are important for the generation of memory B cells and high affinity, isotype-class-switched antibody responses. As described above, the formation of germinal centers is dependent on interaction with Tfh cells. In the germinal centers, B cells proliferate and undergo somatic hypermutation (SHM) and class switch recombination (CSR). SHM increases antibody diversity by introducing point mutations into heavy chain Ig genes. CSR increases diversity further by rearranging the Ig heavy chain genes to express a constant region of a specific Ig antibody class. Initiation of these processes relies on activation-induced cytidine deaminase (Aicda; AID), which creates mutations in DNA by deaminating cytidine residues to generate uracil, leading to base pair mis-matching. Mutated B cells then undergo affinity-driven selection in the germinal centers, which is necessary for the generation of high affinity antibodies and optimal protection against pathogens.
Mechanistic target of rapamycin signaling is critical for the formation of germinal centers and the production of high affinity antibodies. Mice with a hypomorphic allele of mTOR had decreased antibody responses to T-independent and T-dependent antigens, with a more pronounced decrease in IgG compared to IgM antibodies (124). Further analysis of mice with the hypomorphic mTOR allele following immunization with either the model antigen NP-CGG, or heat-killed Pn14 derived from S. pneumoniae showed decreased germinal center formation, SHM, CSR, and IgG antibody affinity maturation (125). Challenge of mice with the hypomorphic mTOR allele with live S. pneumoniae led to reduced antibody titers and survival, compared to wild-type mice (125). Likewise, mice with a B cell-specific deletion of $m$ TOR also had reduced germinal center formation and high affinity antibody generation following immunization with NP-CGG (125). In both cases, decreased mTOR signaling caused a reduction in the RNA and protein levels of AID. Rescue experiments, increasing AID levels in B cells with low mTOR activity, restored CSR, indicating that $\mathrm{mTOR}$ regulates the generation of high affinity antibodies through AID signaling (125).

Consistent with these findings, treatment of mice with a low dose of rapamycin during influenza vaccination blocked germinal center formation, Aicda transcription, and consequently, CSR (137). Furthermore, AID induction was dependent on signaling via mTORC1, as Aicda transcription was not induced in Raptor-deficient B cells following stimulation. In addition, mTOR was critical for CSR independent of proliferation, as the dose of rapamycin used in these experiments was low enough to support proliferation, yet Aicda transcription and CSR were inhibited (137).

Given that high affinity, class-switched antibodies are required for optimal protection against most pathogens, it was surprising that treatment of mice with a low dose of rapamycin during influenza vaccination improved protection against subsequent infections with different influenza subtypes (137). Analysis of the rapamycin-treated mice revealed a block in germinal center formation and CSR, which generated a broader antibody response, rather than a highly selected and affinity-matured repertoire. The majority of antibodies generated during influenza vaccination are high affinity antibodies specific for the globular head of the influenza hemagglutinin (HA) molecule. However, the HA protein is also the most variable protein between different influenza strains. Therefore, highly specific antibodies that protect against one subtype of influenza often do not protect against other subtypes. By blocking germinal center formation, rapamycin hampered the generation of high affinity antibodies specific for the variable region, with the unexpected benefit of allowing the lower affinity antibodies that are specific for conserved portions of influenza to become more prevalent. These data suggest that altering the levels of mTOR activation can steer the immune response away from strain-specific responses to more cross-reactive responses, which would be beneficial in generating a universal influenza vaccine.

It was also reported that mice with a conditional deletion of Tsc1 in B cells, which renders mTOR constitutively active, also had a defect in germinal center formation, and a reduction in $\mathrm{T}$-dependent and T-independent antibody production (128). These data suggest that the level of mTOR activation in B cells is 


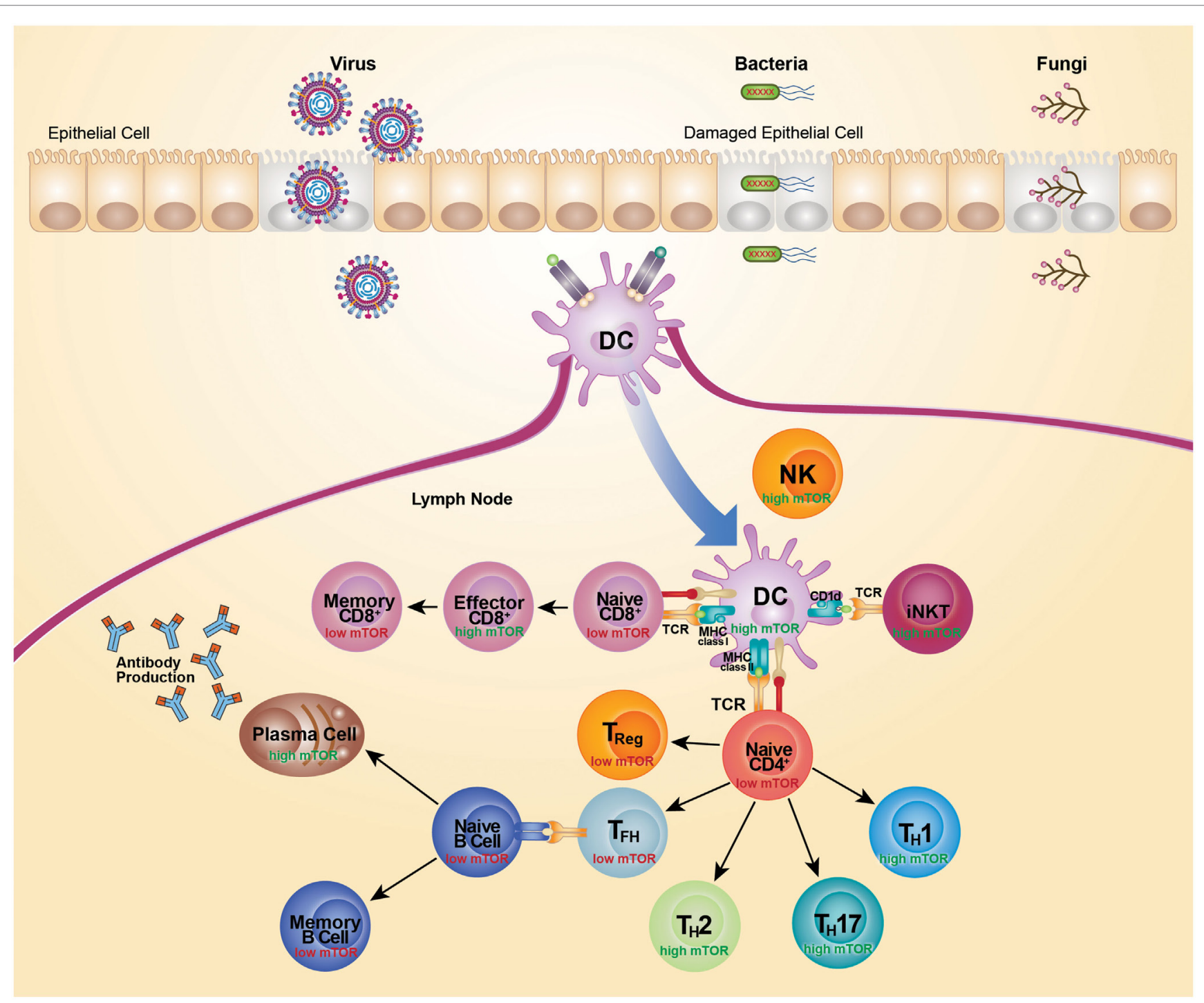

FIGURE 2 | mTOR activity differs across cell subsets. Recognition of microbial components via TLRs leads to activation and subsequent migration of DC from the site of infection to the draining lymph nodes. Activated DCs upregulate costimulatory molecules to become highly efficient antigen-presenting cells. TCR recognition of microbial antigens presented by $D C$ leads to activation and differentiation of CD4+ $T$ cells, $C D 8^{+} T$ cells, and iNKT cells. This TCR-mediated activation is coupled with activation of mTOR and acquisition of effector functions. High mTOR activity is typically associated with high glycolytic and metabolic activity, whereas low mTOR activity is typically associated with low glycolytic activity and a more quiescent state. Activation of naive CD4+ $T$ cells leads to an increase in mTOR activity and expression of transcription factors that promote the differentiation of Th1, Th2, and Th17 cells. Conversely, differentiation of CD4+ T cells in the absence of mTOR signaling promotes development of Treg cells and Tfh cells. Treg cell differentiation is supported by IL-2 and Tfh cell differentiation is suppressed by IL-2. Mature Th cells initiate germinal center reactions and support generation of high affinity isotype-class-switched antibody responses. High mTOR activity also supports the generation of CD8 effectors cells, whereas a dampening of mTOR activity supports the transition to memory CD8 ${ }^{+} \mathrm{T}$ cells. Cells are depicted in their activated state, unless specified as naive or memory.

critical for optimal germinal center formation. However, another group found that mice with a conditional deletion of $T s c 1$ in B cells did not have defects in germinal center formation or high affinity antibody production (129). The reason for the discrepancy in these reports is not clear as both groups observed the same defects in B cell development in the absence of $T s c 1$.

Assessing the role of mTORC2 in antibody generation has also yielded seemingly conflicting data. In one study, inactivation of mTORC2, via Rictor deletion, impaired germinal center differentiation and antibody responses, demonstrating that mTORC2 supports antibody differentiation (127). However, in a subsequent study, partial mTORC2 inhibition through incomplete Rictor deletion increased CSR compared to wild-type mice, illustrating negative regulation of antibody responses by mTORC2 (138). Different levels of Rictor depletion or targeting B cells at different stages of development may have contributed to these discrepancies. The first study reported efficient deletion of Rictor in all hematopietic cells using Vav-cre, or a tamoxifen-inducible 
Cre (127). Whereas Limon and colleagues obtained partial Rictor depletion with CD19-cre (138). In addition, Limon et al. used varying doses of a new class of ATP-competitive mTOR kinase inhibitors to show that partial mTORC2 deletion enhances CSR. Partial deletion of mTORC1 or complete deletion of both mTORC1 and mTORC2 resulted in decreased, rather than increased CSR. However, partial inhibition of both mTOR complexes with inhibitors, or partial deletion of Rictor enhanced CSR. The increase in CSR was dependent on FOXO transcription factors (138). These data again highlight that the level of mTOR activation is a critical determinant on the cellular response.

Tfh cells and B cells act in unison to promote germinal center formation, CSR, and high affinity antibody responses. Yet, mTORC1 signaling typically suppresses Tfh cell development and function, while promoting CSR in B cells. While such a scenario does not create a quandary for cell-specific mTOR signaling, inhibition of the mTOR in the whole organism through either deletion of mTOR or with rapamycin treatment is likely to have opposing affects on antibody formation via Tfh cells and B cells. Similar to the self-regulating mechanism influencing differentiation of Treg cells versus Th1 cells or Tfh versus Th17 cells, the balance between B cell and Tfh cell function may be regulated by as yet unknown mechanisms. Initial inhibition of mTOR could allow development and function of Th cells to promote germinal center formation, followed by a period of enhanced mTOR activity to allow B cell proliferation and CSR to proceed.

\section{CONCLUSION}

It is now clear that mTOR has a central role in coordinating the outcome of pathogen defense by modulating immunity mediated by lymphoid cells. However, many details of the host-pathogen interaction, and their implications, are still to be determined. The mTOR-signaling pathway has a key role in regulating cell metabolism and is therefore readily hijacked by pathogens seeking to acquire energy and control cell death for their own propagation. Survival of a pathogen often necessitates that mTOR pathways are either activated or inactivated,

\section{REFERENCES}

1. Weichhart T, Hengstschläger M, Linke M. Regulation of innate immune cell function by mTOR. Nat Rev Immunol (2015) 15(10):599-614. doi:10.1038/ nri3901

2. Dan HC, Ebbs A, Pasparakis M, Van Dyke T, Basseres DS, Baldwin AS. Akt-dependent activation of mTORC1 complex involves phosphorylation of mTOR (mammalian target of rapamycin) by I $\kappa$ B kinase $\alpha$ (IKK $\alpha$ ). J Biol Chem (2014) 289(36):25227-40. doi:10.1074/jbc.M114.554881

3. Vander Haar E, Lee S-I, Bandhakavi S, Griffin TJ, Kim D-H. Insulin signalling to mTOR mediated by the Akt/PKB substrate PRAS40. Nat Cell Biol (2007) 9(3):316-23. doi:10.1038/ncb1547

4. Mamane Y, Petroulakis E, LeBacquer O, Sonenberg N. mTOR, translation initiation and cancer. Oncogene (2006) 25(48):6416-22. doi:10.1038/ sj.onc. 1209888

5. Beugnet A, Tee AR, Taylor PM, Proud CG. Regulation of targets of mTOR (mammalian target of rapamycin) signalling by intracellular amino acid availability. Biochem J (2003) 372(Pt 2):555-66. doi:10.1042/bj20021266 largely to satisfy particular replication requirements. In turn, the counter immune response also varies depending on the type and dose of the infecting pathogen. Moreover, mTOR signaling varies across responding cell types, cell states, and response kinetics. As mTOR senses the immune microenvironment to direct cellular activation and differentiation, activity of mTOR parallels metabolic activity. Highly glycolytic cells exhibit the highest mTOR activity, while lower mTOR activity is associated with cells more reliant on oxidative phosphorylation for their energy needs (Figure 2). Use of metabolic inhibitors, such as rapamycin, that target the mTOR pathway would preferentially promote responses by more metabolically inactive Treg, Tfh, and memory cells, but would likely do so at the expense of Th1, Th2, Th17, CD8 effector, and antibody responses. As most cellular responses are intimately linked, opposing outcomes would need to be weighed against each other. The outcome of therapeutic intervention is also likely to be highly variable depending on the nature and stage of infection. Moreover, the precise level of mTOR activation is critical for particular immune responses as complete inhibition of a pathway can generate very different outcomes than partial inhibition. Selectively targeting components of the mTOR pathway and metabolic programing may prove more effective in designing vaccine strategies. For example, suppression of mTORC2 has potential for promoting the generation of memory $\mathrm{CD}^{+} \mathrm{T}$ cells, without negatively affecting the development of effector $\mathrm{CD}^{+} \mathrm{T}$ cells. The impact of any therapeutic approach on the metabolic pathway must be thoroughly anticipated and tested as it is clear that there is still much to learn about utilizing the mTOR pathway for successful therapeutic intervention.

\section{AUTHOR CONTRIBUTIONS}

RK and MM researched the literature and wrote the review.

\section{FUNDING}

This work was funded by National Institutes of Health, 1R01AI11472801A1 and ALSAC.

6. Hay N, Sonenberg N. Upstream and downstream of mTOR. Genes Dev (2004) 18(16):1926-45. doi:10.1101/gad.1212704

7. Zinzalla V, Stracka D, Oppliger W, Hall MN. Activation of mTORC2 by association with the ribosome. Cell (2011) 144(5):757-68. doi:10.1016/j. cell.2011.02.014

8. Guertin DA, Stevens DM, Thoreen CC, Burds AA, Kalaany NY, Moffat J, et al. Ablation in mice of the mTORC components raptor, rictor, or mLST8 reveals that mTORC2 is required for signaling to Akt-FOXO and PKCalpha, but not S6K1. Dev Cell (2006) 11(6):859-71. doi:10.1016/j.devcel.2006. 10.007

9. Goncharova EA, Goncharov DA, Li H, Pimtong W, Lu S, Khavin I, et al. mTORC2 is required for proliferation and survival of TSC2-null cells. $\mathrm{Mol}$ Cell Biol (2011) 31(12):2484-98. doi:10.1128/MCB.01061-10

10. Abraham RT, Wiederrecht GJ. Immunopharmacology of rapamycin. Annu Rev Immunol (1996) 14:483-510. doi:10.1146/annurev.immunol.14.1.483

11. Sarbassov DD, Ali SM, Sengupta S, Sheen J-H, Hsu PP, Bagley AF, et al. Prolonged rapamycin treatment inhibits mTORC2 assembly and Akt/PKB. Mol Cell (2006) 22(2):159-68. doi:10.1016/j.molcel.2006.03.029 
12. Sarbassov DD, Guertin DA, Ali SM, Sabatini DM. Phosphorylation and regulation of Akt/PKB by the rictor-mTOR complex. Science (2005) 307(5712):1098-101. doi:10.1126/science.1106148

13. Breuleux M, Klopfenstein M, Stephan C, Doughty CA, Barys L, Maira S-M, et al. Increased AKT 5473 phosphorylation after mTORC1 inhibition is rictor dependent and does not predict tumor cell response to PI3K/mTOR inhibition. Mol Cancer Ther (2009) 8(4):742-53. doi:10.1158/1535-7163. MCT-08-0668

14. Yang G, Murashige DS, Humphrey SJ, James DE. A positive feedback loop between Akt and mTORC2 via SIN1 phosphorylation. Cell Rep (2015) 12(6):937-43. doi:10.1016/j.celrep.2015.07.016

15. Pim D, Massimi P, Dilworth SM, Banks L. Activation of the protein kinase B pathway by the HPV-16 E7 oncoprotein occurs through a mechanism involving interaction with PP2A. Oncogene (2005) 24(53):7830-8. doi:10.1038/ sj.onc. 1208935

16. Spangle JM, Münger K. The human papillomavirus type 16 E6 oncoprotein activates mTORC1 signaling and increases protein synthesis. J Virol (2010) 84(18):9398-407. doi:10.1128/JVI.00974-10

17. Moody CA, Scott RS, Amirghahari N, Nathan C-A, Young LS, Dawson CW, et al. Modulation of the cell growth regulator mTOR by Epstein-Barr virus-encoded LMP2A. JVirol (2005) 79(9):5499-506. doi:10.1128/ JVI.79.9.5499-5506.2005

18. O'Shea C, Klupsch K, Choi S, Bagus B, Soria C, Shen J, et al. Adenoviral proteins mimic nutrient/growth signals to activate the mTOR pathway for viral replication. EMBO J (2005) 24(6):1211-21. doi:10.1038/sj.emboj.7600597

19. Weichhart T, Costantino G, Poglitsch M, Rosner M, Zeyda M, Stuhlmeier KM, et al. The TSC-mTOR signaling pathway regulates the innate inflammatory response. Immunity (2008) 29(4):565-77. doi:10.1016/j.immuni.2008.08.012

20. Kudchodkar SB, Yu Y, Maguire TG, Alwine JC. Human cytomegalovirus infection induces rapamycin-insensitive phosphorylation of downstream effectors of mTOR kinase. J Virol (2004) 78(20):11030-9. doi:10.1128/ JVI.78.20.11030-11039.2004

21. Jaramillo M, Gomez MA, Larsson O, Shio MT, Topisirovic I, Contreras I, et al. Leishmania repression of host translation through mTOR cleavage is required for parasite survival and infection. Cell Host Microbe (2011) 9(4):331-41. doi:10.1016/j.chom.2011.03.008

22. Yakoub AM, Shukla D. Autophagy stimulation abrogates herpes simplex virus-1 infection. Sci Rep (2015) 5:9730. doi:10.1038/srep09730

23. Kim YC, Guan K-L. mTOR: a pharmacologic target for autophagy regulation. J Clin Invest (2015) 125(1):25-32. doi:10.1172/JCI73939

24. Tattoli I, Sorbara MT, Yang C, Tooze SA, Philpott DJ, Girardin SE. Listeria phospholipases subvert host autophagic defenses by stalling preautophagosomal structures. EMBO J (2013) 32(23):3066-78. doi:10.1038/ emboj.2013.234

25. Gutierrez MG, Master SS, Singh SB, Taylor GA, Colombo MI, Deretic V. Autophagy is a defense mechanism inhibiting BCG and Mycobacterium tuberculosis survival in infected macrophages. Cell (2004) 119(6):753-66. doi:10.1016/j.cell.2004.11.038

26. Yakoub AM, Shukla D. Basal autophagy is required for herpes simplex virus-2 infection. Sci Rep (2015) 5:12985. doi:10.1038/srep12985

27. Tattoli I, Sorbara MT, Vuckovic D, Ling A, Soares F, Carneiro LAM, et al. Amino acid starvation induced by invasive bacterial pathogens triggers an innate host defense program. Cell Host Microbe (2012) 11(6):563-75. doi:10.1016/j.chom.2012.04.012

28. Zhu H, Han L, Shi X, Wang B, Huang H, Wang X, et al. Baicalin inhibits autophagy induced by influenza A virus H3N2. Antiviral Res (2015) 113:62-70. doi:10.1016/j.antiviral.2014.11.003

29. Ma J, Sun Q, Mi R, Zhang H. Avian influenza A virus H5N1 causes autophagy-mediated cell death through suppression of mTOR signaling. J Genet Genomics (2011) 38(11):533-7. doi:10.1016/j.jgg.2011.10.002

30. Datan E, Shirazian A, Benjamin S, Matassov D, Tinari A, Malorni W, et al. $\mathrm{mTOR} / \mathrm{p} 70 \mathrm{~S} 6 \mathrm{~K}$ signaling distinguishes routine, maintenance-level autophagy from autophagic cell death during influenza A infection. Virology (2014) 45(2-453):175-90. doi:10.1016/j.virol.2014.01.008

31. Marçais A, Cherfils-Vicini J, Viant C, Degouve S, Viel S, Fenis A, et al. The metabolic checkpoint kinase mTOR is essential for IL-15 signaling during the development and activation of NK cells. Nat Immunol (2014) 15(8):749-57. doi:10.1038/ni.2936
32. Wai L-E, Fujiki M, Takeda S, Martinez OM, Krams SM. Rapamycin, but not cyclosporine or FK506, alters natural killer cell function. Transplantation (2008) 85(1):145-9. doi:10.1097/01.tp.0000296817.28053.7b

33. Nandagopal N, Ali AK, Komal AK, Lee S-H. The critical role of IL-15-PI3KmTOR pathway in natural killer cell effector functions. Front Immunol (2014) 5:187. doi:10.3389/fimmu.2014.00187

34. Eissens DN, Van Der Meer A, Van Cranenbroek B, Preijers FWMB, Joosten I. Rapamycin and MPA, but not CsA, impair human NK cell cytotoxicity due to differential effects on NK cell phenotype. Am J Transplant (2010) 10(9):1981-90. doi:10.1111/j.1600-6143.2010.03242.x

35. Donnelly RP, Loftus RM, Keating SE, Liou KT, Biron CA, Gardiner CM, et al. mTORC1-dependent metabolic reprogramming is a prerequisite for NK cell effector function. J Immunol (2014) 193(9):4477-84. doi:10.4049/ jimmunol.1401558

36. Ripoli M, D’Aprile A, Quarato G, Sarasin-Filipowicz M, Gouttenoire J, Scrima R, et al. Hepatitis $\mathrm{C}$ virus-linked mitochondrial dysfunction promotes hypoxia-inducible factor 1 alpha-mediated glycolytic adaptation. JVirol (2010) 84(1):647-60. doi:10.1128/JVI.00769-09

37. Arase H, Mocarski ES, Campbell AE, Hill AB, Lanier LL. Direct recognition of cytomegalovirus by activating and inhibitory NK cell receptors. Science (2002) 296(5571):1323-6. doi:10.1126/science.1070884

38. Sun JC, Ma A, Lanier LL. Cutting edge: IL-15-independent NK cell response to mouse cytomegalovirus infection. J Immunol (2009) 183(5):2911-4. doi:10.4049/jimmunol.0901872

39. Lee YJ, Holzapfel KL, Zhu J, Jameson SC, Hogquist KA. Steady-state production of IL-4 modulates immunity in mouse strains and is determined by lineage diversity of iNKT cells. Nat Immunol (2013) 14(11):1146-54. doi:10.1038/ni.2731

40. Constantinides MG, Bendelac A. Transcriptional regulation of the NKT cell lineage. Curr Opin Immunol (2013) 25(2):161-7. doi:10.1016/j. coi.2013.01.003

41. Zhang L, Tschumi BO, Corgnac S, Rüegg MA, Hall MN, Mach J-P, et al. Mammalian target of rapamycin complex 1 orchestrates invariant NKT cell differentiation and effector function. J Immunol (2014) 193(4):1759-65. doi:10.4049/jimmunol.1400769

42. Shin J, Wang S, Deng W, Wu J, Gao J, Zhong X-P. Mechanistic target of rapamycin complex 1 is critical for invariant natural killer T-cell development and effector function. Proc Natl Acad Sci U S A (2014) 111(8):E776-83. doi:10.1073/pnas.1315435111

43. Wei J, Yang K, Chi H. Cutting edge: discrete functions of mTOR signaling in invariant NKT cell development and NKT17 fate decision. J Immunol (2014) 193(9):4297-301. doi:10.4049/jimmunol.1402042

44. Prevot N, Pyaram K, Bischoff E, Sen JM, Powell JD, Chang C-H. Mammalian target of rapamycin complex 2 regulates invariant NKT cell development and function independent of promyelocytic leukemia zinc-finger. J Immunol (2015) 194(1):223-30. doi:10.4049/jimmunol.1401985

45. Huijts CM, Schneiders FL, Garcia-Vallejo JJ, Verheul HM, de Gruijl TD, van der Vliet HJ. mTOR inhibition per se induces nuclear localization of FOXP3 and conversion of invariant NKT (iNKT) cells into immunosuppressive regulatory iNKT cells. JImmunol (2015) 195(5):2038-45. doi:10.4049/ jimmunol.1402710

46. Wu J, Shin J, Xie D, Wang H, Gao J, Zhong X-P. Tuberous sclerosis 1 promotes invariant NKT cell anergy and inhibits invariant NKT cell-mediated antitumor immunity. J Immunol (2014) 192(6):2643-50. doi:10.4049/ jimmunol.1302076

47. Gonzalez-Aseguinolaza G, Van Kaer L, Bergmann CC, Wilson JM, Schmieg J, Kronenberg M, et al. Natural killer T cell ligand alpha-galactosylceramide enhances protective immunity induced by malaria vaccines. J Exp Med (2002) 195(5):617-24. doi:10.1084/jem.20011889

48. Huang Y, Chen A, Li X, Chen Z, Zhang W, Song Y, et al. Enhancement of HIV DNA vaccine immunogenicity by the NKT cell ligand, alpha-galactosylceramide. Vaccine (2008) 26(15):1807-16. doi:10.1016/j.vaccine.2008. 02.002

49. Youn H-J, Ko S-Y, Lee K-A, Ko H-J, Lee Y-S, Fujihashi K, et al. A single intranasal immunization with inactivated influenza virus and alpha-galactosylceramide induces long-term protective immunity without redirecting antigen to the central nervous system. Vaccine (2007) 25(28):5189-98. doi:10.1016/j.vaccine.2007.04.081 
50. Shibolet O, Alper R, Zlotogarov L, Thalenfeld B, Engelhardt D, Rabbani E, et al. NKT and CD8 lymphocytes mediate suppression of hepatocellular carcinoma growth via tumor antigen-pulsed dendritic cells. Int J Cancer (2003) 106(2):236-43. doi:10.1002/ijc.11201

51. Kawakami K, Yamamoto N, Kinjo Y, Miyagi K, Nakasone C, Uezu K, et al. Critical role of Valpha14+ natural killer T cells in the innate phase of host protection against Streptococcus pneumoniae infection. Eur J Immunol (2003) 33(12):3322-30. doi:10.1002/eji.200324254

52. Kinjo Y, Tupin E, Wu D, Fujio M, Garcia-Navarro R, Benhnia MR-E-I, et al. Natural killer $\mathrm{T}$ cells recognize diacylglycerol antigens from pathogenic bacteria. Nat Immunol (2006) 7(9):978-86. doi:10.1038/ni1380

53. Mattner J, Savage PB, Leung P, Oertelt SS, Wang V, Trivedi O, et al. Liver autoimmunity triggered by microbial activation of natural killer $\mathrm{T}$ cells. Cell Host Microbe (2008) 3(5):304-15. doi:10.1016/j.chom.2008. 03.009

54. Delgoffe GM, Kole TP, Cotter RJ, Powell JD. Enhanced interaction between Hsp90 and raptor regulates mTOR signaling upon T cell activation. Mol Immunol (2009) 46(13):2694-8. doi:10.1016/j.molimm.2009.05.185

55. Yamada T, Gierach K, Lee P-H, Wang X, Lacorazza HD. Cutting edge: expression of the transcription factor E74-like factor 4 is regulated by the mammalian target of rapamycin pathway in CD8+ T cells. J Immunol (2010) 185(7):3824-8. doi:10.4049/jimmunol.1000718

56. Maciver NJ, Jacobs SR, Wieman HL, Wofford JA, Coloff JL, Rathmell JC. Glucose metabolism in lymphocytes is a regulated process with significant effects on immune cell function and survival. J Leukoc Biol (2008) 84(4):94957. doi:10.1189/jlb.0108024

57. Pollizzi KN, Patel CH, Sun I-H, Oh M-H, Waickman AT, Wen J, et al. mTORC1 and mTORC2 selectively regulate $\mathrm{CD} 8^{+} \mathrm{T}$ cell differentiation. J Clin Invest (2015) 125(5):2090-108. doi:10.1172/JCI77746

58. Finlay DK, Rosenzweig E, Sinclair LV, Feijoo-Carnero C, Hukelmann JL, Rolf J, et al. PDK1 regulation of mTOR and hypoxia-inducible factor 1 integrate metabolism and migration of CD8+ T cells. JExp Med (2012) 209(13):2441-53. doi:10.1084/jem.20112607

59. Goldberg EL, Smithey MJ, Lutes LK, Uhrlaub JL, Nikolich-Žugich J. Immune memory-boosting dose of rapamycin impairs macrophage vesicle acidification and curtails glycolysis in effector CD8 cells, impairing defense against acute infections. J Immunol (2014) 193(2):757-63. doi:10.4049/ jimmunol.1400188

60. Wang R, Dillon CP, Shi LZ, Milasta S, Carter R, Finkelstein D, et al. The transcription factor Myc controls metabolic reprogramming upon T lymphocyte activation. Immunity (2011) 35(6):871-82. doi:10.1016/j. immuni.2011.09.021

61. Yao S, Buzo BF, Pham D, Jiang L, Taparowsky EJ, Kaplan MH, et al. Interferon regulatory factor 4 sustains $\mathrm{CD} 8(+) \mathrm{T}$ cell expansion and effector differentiation. Immunity (2013) 39(5):833-45. doi:10.1016/j.immuni.2013.10.007

62. Man K, Miasari M, Shi W, Xin A, Henstridge DC, Preston S, et al. The transcription factor IRF4 is essential for TCR affinity-mediated metabolic programming and clonal expansion of T cells. Nat Immunol (2013) 14(11):1155-65. doi:10.1038/ni.2710

63. Ito D, Nojima S, Nishide M, Okuno T, Takamatsu H, Kang S, et al. mTOR complex signaling through the SEMA4A-Plexin B2 axis is required for optimal activation and differentiation of CD8+ T cells. J Immunol (2015) 195(3):934-43. doi:10.4049/jimmunol.1403038

64. Finlay D, Cantrell D. Phosphoinositide 3-kinase and the mammalian target of rapamycin pathways control T cell migration. Ann N Y Acad Sci (2010) 1183:149-57. doi:10.1111/j.1749-6632.2009.05134.x

65. Sinclair LV, Finlay D, Feijoo C, Cornish GH, Gray A, Ager A, et al. Phosphatidylinositol-3-OH kinase and nutrient-sensing mTOR pathways control T lymphocyte trafficking. Nat Immunol (2008) 9(5):513-21. doi:10.1038/ni.1603

66. van der Windt GJW, Everts B, Chang C-H, Curtis JD, Freitas TC, Amiel E, et al. Mitochondrial respiratory capacity is a critical regulator of CD8+ $\mathrm{T}$ cell memory development. Immunity (2012) 36(1):68-78. doi:10.1016/j. immuni.2011.12.007

67. Araki K, Turner AP, Shaffer VO, Gangappa S, Keller SA, Bachmann MF, et al. mTOR regulates memory CD8 T-cell differentiation. Nature (2009) 460(7251):108-12. doi:10.1038/nature08155
68. Pearce EL, Walsh MC, Cejas PJ, Harms GM, Shen H, Wang L-S, et al. Enhancing CD8 T-cell memory by modulating fatty acid metabolism. Nature (2009) 460(7251):103-7. doi:10.1038/nature08097

69. He S, Kato K, Jiang J, Wahl DR, Mineishi S, Fisher EM, et al. Characterization of the metabolic phenotype of rapamycin-treated CD8+ T cells with augmented ability to generate long-lasting memory cells. PLoS One (2011) 6(5):e20107. doi:10.1371/journal.pone.0020107

70. Shrestha S, Yang K, Wei J, Karmaus PWF, Neale G, Chi H. Tscl promotes the differentiation of memory $\mathrm{CD} 8+\mathrm{T}$ cells via orchestrating the transcriptional and metabolic programs. Proc Natl Acad Sci U S A (2014) 111(41):14858-63. doi:10.1073/pnas.1404264111

71. Li Q, Rao R, Vazzana J, Goedegebuure P, Odunsi K, Gillanders W, et al. Regulating mammalian target of rapamycin to tune vaccination-induced CD8(+) T cell responses for tumor immunity. JImmunol (2012) 188(7):3080-7. doi:10.4049/jimmunol.1103365

72. Stoycheva D, Deiser K, Stärck L, Nishanth G, Schlüter D, Uckert W, et al. IFN- $\gamma$ regulates $\mathrm{CD} 8+$ memory T cell differentiation and survival in response to weak, but not strong, TCR signals. J Immunol (2015) 194(2):553-9. doi: 10.4049/jimmunol.1402058

73. Cukalac T, Chadderton J, Zeng W, Cullen JG, Kan WT, Doherty PC, et al. The influenza virus-specific CTL immunodominance hierarchy in mice is determined by the relative frequency of high-avidity $\mathrm{T}$ cells. J Immunol (2014) 192(9):4061-8. doi:10.4049/jimmunol.1301403

74. Rao RR, Li Q, Odunsi K, Shrikant PA. The mTOR kinase determines effector versus memory CD8+ $\mathrm{T}$ cell fate by regulating the expression of transcription factors T-bet and Eomesodermin. Immunity (2010) 32(1):67-78. doi:10.1016/j.immuni.2009.10.010

75. Li Q, Rao RR, Araki K, Pollizzi K, Odunsi K, Powell JD, et al. A central role for mTOR kinase in homeostatic proliferation induced CD8+ T cell memory and tumor immunity. Immunity (2011) 34(4):541-53. doi:10.1016/j. immuni.2011.04.006

76. Garcia K, Sun Z, Mattson E, Li L, Smyth K, Xiao Z. IL-12 is required for mTOR regulation of memory CTLs during viral infection. Genes Immun (2014) 15(6):413-23. doi:10.1038/gene.2014.33

77. Mehlhop-Williams ER, Bevan MJ. Memory CD8+ T cells exhibit increased antigen threshold requirements for recall proliferation. J Exp Med (2014) 211(2):345-56. doi:10.1084/jem.20131271

78. Richer MJ, Pewe LL, Hancox LS, Hartwig SM, Varga SM, Harty JT. Inflammatory IL-15 is required for optimal memory $\mathrm{T}$ cell responses. J Clin Invest (2015) 125(9):3477-90. doi:10.1172/JCI81261

79. Staron MM, Gray SM, Marshall HD, Parish IA, Chen JH, Perry CJ, et al. The transcription factor FoxO1 sustains expression of the inhibitory receptor PD-1 and survival of antiviral CD8(+) T cells during chronic infection. Immunity (2014) 41(5):802-14. doi:10.1016/j.immuni.2014.10.013

80. Wherry EJ. T cell exhaustion. Nat Immunol (2011) 12(6):492-9. doi:10.1038/ ni.2035

81. Klonowski KD, Williams KJ, Marzo AL, Blair DA, Lingenheld EG, Lefrançois L. Dynamics of blood-borne CD8 memory T cell migration in vivo. Immunity (2004) 20(5):551-62. doi:10.1016/S1074-7613(04)00103-7

82. Masopust D, Choo D, Vezys V, Wherry EJ, Duraiswamy J, Akondy R, et al. Dynamic $T$ cell migration program provides resident memory within intestinal epithelium. J Exp Med (2010) 207(3):553-64. doi:10.1084/jem.20090858

83. Schenkel JM, Fraser KA, Beura LK, Pauken KE, Vezys V, Masopust D. $\mathrm{T}$ cell memory. Resident memory CD8 $\mathrm{T}$ cells trigger protective innate and adaptive immune responses. Science (2014) 346(6205):98-101. doi:10.1126/ science. 1254536

84. Sowell RT, Rogozinska M, Nelson CE, Vezys V, Marzo AL. Cutting edge: generation of effector cells that localize to mucosal tissues and form resident memory CD8 T cells is controlled by mTOR. J Immunol (2014) 193(5):206771. doi:10.4049/jimmunol.1400074

85. Brown DM, Dilzer AM, Meents DL, Swain SL. CD4 T cell-mediated protection from lethal influenza: perforin and antibody-mediated mechanisms give a one-two punch. JImmunol (2006) 177(5):2888-98. doi:10.4049/ jimmunol.177.5.2888

86. McKinstry KK, Strutt TM, Kuang Y, Brown DM, Sell S, Dutton RW, et al. Memory CD4+ T cells protect against influenza through multiple synergizing mechanisms. J Clin Invest (2012) 122(8):2847-56. doi:10.1172/JCI63689 
87. Powell JD, Pollizzi KN, Heikamp EB, Horton MR. Regulation of immune responses by mTOR. Annu Rev Immunol (2012) 30:39-68. doi:10.1146/ annurev-immunol-020711-075024

88. Zhu J, Yamane H, Paul WE. Differentiation of effector CD4 T cell populations $\left(^{*}\right)$. Annu Rev Immunol (2010) 28:445-89. doi:10.1146/ annurev-immunol-030409-101212

89. Delgoffe GM, Kole TP, Zheng Y, Zarek PE, Matthews KL, Xiao B, et al. The mTOR kinase differentially regulates effector and regulatory $\mathrm{T}$ cell lineage commitment. Immunity (2009) 30(6):832-44. doi:10.1016/j. immuni.2009.04.014

90. Powell JD, Delgoffe GM. The mammalian target of rapamycin: linking T cell differentiation, function, and metabolism. Immunity (2010) 33(3):301-11. doi:10.1016/j.immuni.2010.09.002

91. Delgoffe GM, Pollizzi KN, Waickman AT, Heikamp E, Meyers DJ, Horton MR, et al. The kinase mTOR regulates the differentiation of helper T cells through the selective activation of signaling by mTORC1 and mTORC2. Nat Immunol (2011) 12(4):295-303. doi:10.1038/ni.2005

92. Kurebayashi Y, Nagai S, Ikejiri A, Ohtani M, Ichiyama K, Baba Y, et al. PI3K-Akt-mTORC1-S6K1/2 axis controls Th17 differentiation by regulating Gfil expression and nuclear translocation of ROR $\gamma$. Cell Rep (2012) 1(4):360-73. doi:10.1016/j.celrep.2012.02.007

93. Yang K, Shrestha S, Zeng H, Karmaus PWF, Neale G, Vogel P, et al. $\mathrm{T}$ cell exit from quiescence and differentiation into Th2 cells depend on Raptor-mTORC1-mediated metabolic reprogramming. Immunity (2013) 39(6):1043-56. doi:10.1016/j.immuni.2013.09.015

94. Lee K, Gudapati P, Dragovic S, Spencer C, Joyce S, Killeen N, et al. Mammalian target of rapamycin protein complex 2 regulates differentiation of Th1 and Th2 cell subsets via distinct signaling pathways. Immunity (2010) 32(6):743-53. doi:10.1016/j.immuni.2010.06.002

95. Michalek RD, Gerriets VA, Jacobs SR, Macintyre AN, MacIver NJ, Mason EF, et al. Cutting edge: distinct glycolytic and lipid oxidative metabolic programs are essential for effector and regulatory CD4+ T cell subsets. JImmunol (2011) 186(6):3299-303. doi:10.4049/jimmunol.1003613

96. Shi LZ, Wang R, Huang G, Vogel P, Neale G, Green DR, et al. HIF1alphadependent glycolytic pathway orchestrates a metabolic checkpoint for the differentiation of TH17 and Treg cells. J Exp Med (2011) 208(7):1367-76. doi:10.1084/jem.20110278

97. Dang EV, Barbi J, Yang H-Y, Jinasena D, Yu H, Zheng Y, et al. Control of $\mathrm{T}(\mathrm{H}) 17 / \mathrm{T}(\mathrm{reg})$ balance by hypoxia-inducible factor 1. Cell (2011) 146(5):772-84. doi:10.1016/j.cell.2011.07.033

98. Sanchez AM, Yang Y. The role of natural regulatory $\mathrm{T}$ cells in infection. Immunol Res (2011) 49(1-3):124-34. doi:10.1007/s12026-010-8176-8

99. Fontenot JD, Rudensky AY. A well adapted regulatory contrivance: regulatory T cell development and the forkhead family transcription factor Foxp3. Nat Immunol (2005) 6(4):331-7. doi:10.1038/ni1179

100. Sakaguchi S, Ono M, Setoguchi R, Yagi H, Hori S, Fehervari Z, et al. Foxp3+ CD25+ CD4+ natural regulatory $\mathrm{T}$ cells in dominant self-tolerance and autoimmune disease. Immunol Rev (2006) 212:8-27. doi:10.1111/j.0105-2896.2006.00427.x

101. Battaglia M, Stabilini A, Roncarolo M-G. Rapamycin selectively expands CD4+CD25+FoxP3+ regulatory T cells. Blood (2005) 105(12):4743-8. doi:10.1182/blood-2004-10-3932

102. Battaglia M, Stabilini A, Migliavacca B, Horejs-Hoeck J, Kaupper T, Roncarolo M-G. Rapamycin promotes expansion of functional CD4+CD25+FOXP3+ regulatory $\mathrm{T}$ cells of both healthy subjects and type 1 diabetic patients. J Immunol (2006) 177(12):8338-47. doi:10.4049/ jimmunol.177.12.8338

103. Haxhinasto S, Mathis D, Benoist C. The AKT-mTOR axis regulates de novo differentiation of CD4+Foxp3+ cells. J Exp Med (2008) 205(3):565-74. doi:10.1084/jem.20071477

104. Gao W, Lu Y, El Essawy B, Oukka M, Kuchroo VK, Strom TB. Contrasting effects of cyclosporine and rapamycin in de novo generation of alloantigen-specific regulatory T cells. Am J Transplant (2007) 7(7):1722-32. doi:10.1111/j.1600-6143.2007.01842.x

105. Valmori D, Tosello V, Souleimanian NE, Godefroy E, Scotto L, Wang Y, et al. Rapamycin-mediated enrichment of $\mathrm{T}$ cells with regulatory activity in stimulated CD4+ T cell cultures is not due to the selective expansion of naturally occurring regulatory $\mathrm{T}$ cells but to the induction of regulatory functions in conventional CD4+ T cells. J Immunol (2006) 177(2):944-9. doi:10.4049/ jimmunol.177.2.944

106. Kopf H, de la Rosa GM, Howard OMZ, Chen X. Rapamycin inhibits differentiation of Th17 cells and promotes generation of FoxP3+ T regulatory cells. Int Immunopharmacol (2007) 7(13):1819-24. doi:10.1016/j.intimp.2007.08.027

107. Yurchenko E, Shio MT, Huang TC, Da Silva Martins M, Szyf M, Levings $\mathrm{MK}$, et al. Inflammation-driven reprogramming of CD4+ Foxp3+ regulatory T cells into pathogenic Th1/Th17 T effectors is abrogated by mTOR inhibition in vivo. PLoS One (2012) 7(4):e35572. doi:10.1371/journal.pone.0035572

108. Gulen MF, Kang Z, Bulek K, Youzhong W, Kim TW, Chen Y, et al. The receptor SIGIRR suppresses Th17 cell proliferation via inhibition of the interleukin-1 receptor pathway and mTOR kinase activation. Immunity (2010) 32(1):54-66. doi:10.1016/j.immuni.2009.12.003

109. Gabryšová L, Christensen JR, Wu X, Kissenpfennig A, Malissen B, O’Garra A. Integrated $\mathrm{T}$-cell receptor and costimulatory signals determine TGF- $\beta$ dependent differentiation and maintenance of Foxp3+ regulatory $\mathrm{T}$ cells. Eur J Immunol (2011) 41(5):1242-8. doi:10.1002/eji.201041073

110. Liu G, Yang K, Burns S, Shrestha S, Chi H. The S1P(1)-mTOR axis directs the reciprocal differentiation of T(H)1 and T(reg) cells. Nat Immunol (2010) 11(11):1047-56. doi:10.1038/ni.1939

111. Zeng H, Yang K, Cloer C, Neale G, Vogel P, Chi H. mTORC1 couples immune signals and metabolic programming to establish T(reg)-cell function. Nature (2013) 499(7459):485-90. doi:10.1038/nature12297

112. Crotty S. Follicular helper CD4 T cells (TFH). Annu Rev Immunol (2011) 29:621-63. doi:10.1146/annurev-immunol-031210-101400

113. Johnston RJ, Poholek AC, DiToro D, Yusuf I, Eto D, Barnett B, et al. Bcl6 and Blimp-1 are reciprocal and antagonistic regulators of $\mathrm{T}$ follicular helper cell differentiation. Science (2009) 325(5943):1006-10. doi:10.1126/ science. 1175870

114. Poholek AC, Hansen K, Hernandez SG, Eto D, Chandele A, Weinstein JS, et al. In vivo regulation of $\mathrm{Bcl} 6$ and $\mathrm{T}$ follicular helper cell development. J Immunol (2010) 185(1):313-26. doi:10.4049/jimmunol.0904023

115. Choi YS, Kageyama R, Eto D, Escobar TC, Johnston RJ, Monticelli L, et al. ICOS receptor instructs T follicular helper cell versus effector cell differentiation via induction of the transcriptional repressor Bcl6. Immunity (2011) 34(6):932-46. doi:10.1016/j.immuni.2011.03.023

116. Choi YS, Yang JA, Yusuf I, Johnston RJ, Greenbaum J, Peters B, et al. Bcl6 expressing follicular helper CD4 T cells are fate committed early and have the capacity to form memory. J Immunol (2013) 190(8):4014-26. doi:10.4049/ jimmunol.1202963

117. Ray JP, Marshall HD, Laidlaw BJ, Staron MM, Kaech SM, Craft J. Transcription factor STAT3 and type I interferons are corepressive insulators for differentiation of follicular helper and T helper 1 cells. Immunity (2014) 40(3):367-77. doi:10.1016/j.immuni.2014.02.005

118. Ray JP, Staron MM, Shyer JA, Ho P-C, Marshall HD, Gray SM, et al. The interleukin-2-mTORc1 kinase axis defines the signaling, differentiation, and metabolism of T helper 1 and follicular B helper T Cells. Immunity (2015) 43(4):690-702. doi:10.1016/j.immuni.2015.08.017

119. Pepper M, Pagán AJ, Igyártó BZ, Taylor JJ, Jenkins MK. Opposing signals from the Bcl6 transcription factor and the interleukin-2 receptor generate T helper 1 central and effector memory cells. Immunity (2011) 35(4):583-95. doi:10.1016/j.immuni.2011.09.009

120. Choi YS, Eto D, Yang JA, Lao C, Crotty S. Cutting edge: STAT1 is required for IL-6-mediated Bcl6 induction for early follicular helper cell differentiation. J Immunol (2013) 190(7):3049-53. doi:10.4049/jimmunol.1203032

121. Ballesteros-Tato A, León B, Graf BA, Moquin A, Adams PS, Lund FE, et al. Interleukin-2 inhibits germinal center formation by limiting $\mathrm{T}$ follicular helper cell differentiation. Immunity (2012) 36(5):847-56. doi:10.1016/j. immuni.2012.02.012

122. Marshall HD, Ray JP, Laidlaw BJ, Zhang N, Gawande D, Staron MM, et al. The transforming growth factor beta signaling pathway is critical for the formation of CD4 $\mathrm{T}$ follicular helper cells and isotype-switched antibody responses in the lung mucosa. eLife (2015) 4:e04851. doi:10.7554/ eLife.04851

123. Oestreich KJ, Read KA, Gilbertson SE, Hough KP, McDonald PW, Krishnamoorthy $\mathrm{V}$, et al. Bcl-6 directly represses the gene program of the glycolysis pathway. Nat Immunol (2014) 15(10):957-64. doi:10.1038/ ni. 2985 
124. Zhang S, Readinger JA, DuBois W, Janka-Junttila M, Robinson R, Pruitt M, et al. Constitutive reductions in mTOR alter cell size, immune cell development, and antibody production. Blood (2011) 117(4):1228-38. doi:10.1182/ blood-2010-05-287821

125. Zhang S, Pruitt M, Tran D, Du Bois W, Zhang K, Patel R, et al. B cell-specific deficiencies in mTOR limit humoral immune responses. J Immunol (2013) 191(4):1692-703. doi:10.4049/jimmunol.1201767

126. Lazorchak AS, Liu D, Facchinetti V, Di Lorenzo A, Sessa WC, Schatz DG, et al. Sin1-mTORC2 suppresses rag and il7r gene expression through Akt2 in B cells. Mol Cell (2010) 39(3):433-43. doi:10.1016/j.molcel.2010.07.031

127. Lee K, Heffington L, Jellusova J, Nam KT, Raybuck A, Cho SH, et al. Requirement for Rictor in homeostasis and function of mature B lymphoid cells. Blood (2013) 122(14):2369-79. doi:10.1182/blood-2013-01477505

128. Benhamron S, Tirosh B. Direct activation of mTOR in B lymphocytes confers impairment in B-cell maturation andloss of marginal zone B cells. Eur J Immunol (2011) 41(8):2390-6. doi:10.1002/eji.201041336

129. Ci X, Kuraoka M, Wang H, Carico Z, Hopper K, Shin J, et al. TSC1 promotes $\mathrm{B}$ cell maturation but is dispensable for germinal center formation. PLoS One (2015) 10(5):e0127527. doi:10.1371/journal.pone.0127527

130. Donahue AC, Fruman DA. Distinct signaling mechanisms activate the target of rapamycin in response to different B-cell stimuli. Eur J Immunol (2007) 37(10):2923-36. doi:10.1002/eji.200737281

131. Donahue AC, Fruman DA. Proliferation and survival of activated B cells requires sustained antigen receptor engagement and phosphoinositide 3-kinase activation. J Immunol (2003) 170(12):5851-60.

132. Sakata A, Kuwahara K, Ohmura T, Inui S, Sakaguchi N. Involvement of a rapamycin-sensitive pathway in CD40-mediated activation of murine B cells in vitro. Immunol Lett (1999) 68(2-3):301-9. doi:10.1016/ S0165-2478(99)00053-X
133. Wicker LS, Boltz RC Jr, Matt V, Nichols EA, Peterson LB, Sigal NH. Suppression of B cell activation by cyclosporin A, FK506 and rapamycin. Eur J Immunol (1990) 20(10):2277-83. doi:10.1002/eji.1830201017

134. Kay JE, Kromwel L, Doe SE, Denyer M. Inhibition of T and B lymphocyte proliferation by rapamycin. Immunology (1991) 72(4):544-9.

135. Aagaard-Tillery KM, Jelinek DF. Inhibition of human B lymphocyte cell cycle progression and differentiation by rapamycin. Cell Immunol (1994) 156(2):493-507. doi:10.1006/cimm.1994.1193

136. Zeng Q, Zhang H, Qin J, Xu Z, Gui L, Liu B, et al. Rapamycin inhibits BAFFstimulated cell proliferation and survival by suppressing mTOR-mediated PP2A-Erk1/2 signaling pathway in normal and neoplastic B-lymphoid cells. Cell Mol Life Sci (2015) 72(24):4867-84. doi:10.1007/s00018-015-1976-1

137. Keating R, Hertz T, Wehenkel M, Harris TL, Edwards BA, McClaren JL, et al. The kinase mTOR modulates the antibody response to provide cross-protective immunity to lethal infection with influenza virus. Nat Immunol (2013) 14(12):1266-76. doi:10.1038/ni.2741

138. Limon JJ, So L, Jellbauer S, Chiu H, Corado J, Sykes SM, et al. mTOR kinase inhibitors promote antibody class switching via mTORC2 inhibition. Proc Natl Acad Sci U S A (2014) 111(47):E5076-85. doi:10.1073/pnas.1407104111

Conflict of Interest Statement: The authors declare that the research was conducted in the absence of any commercial or financial relationships that could be construed as a potential conflict of interest.

Copyright $\odot 2016$ Keating and McGargill. This is an open-access article distributed under the terms of the Creative Commons Attribution License (CC BY). The use, distribution or reproduction in other forums is permitted, provided the original author(s) or licensor are credited and that the original publication in this journal is cited, in accordance with accepted academic practice. No use, distribution or reproduction is permitted which does not comply with these terms. 